\title{
LEVEL II SCOUR ANALYSIS FOR BRIDGE 6 (RICHTH00030006) on TOWN HIGHWAY 3, crossing an UNNAMED TRIBUTARY TO THE MISSISQUOI RIVER, RICHFORD, VERMONT
}

U.S. Geological Survey Open-File Report 96-635

Prepared in cooperation with

VERMONT AGENCY OF TRANSPORTATION and

FEDERAL HIGHWAY ADMINISTRATION 


\section{LEVEL II SCOUR ANALYSIS FOR BRIDGE 6 (RICHTH00030006) on TOWN HIGHWAY 3, crossing an UNNAMED TRIBUTARY TO THE MISSISQUOI RIVER, RICHFORD, VERMONT}

BY ROBERT H. FLYNN AND DONALD L. SONG

U.S. Geological Survey Open-File Report 96-635 


\title{
U.S. DEPARTMENT OF THE INTERIOR BRUCE BABBITT, Secretary
}

\author{
U.S. GEOLOGICAL SURVEY \\ Gordon P. Eaton, Director
}

For additional information write to:

District Chief

U.S. Geological Survey 361 Commerce Way

Pembroke, NH 03275-3718
Copies of this report may be purchased from:

U.S. Geological Survey

Branch of Information Services

Open-File Reports Unit

Box 25286

Denver, CO 80225-0286 


\section{CONTENTS}

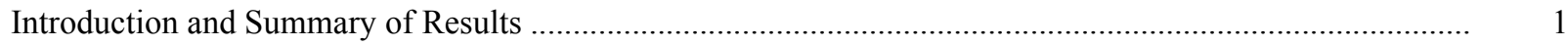

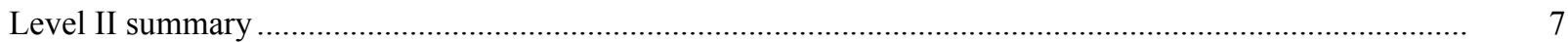

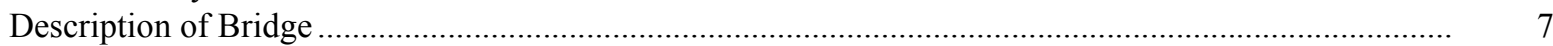

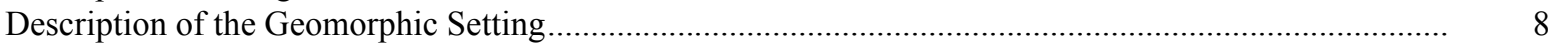

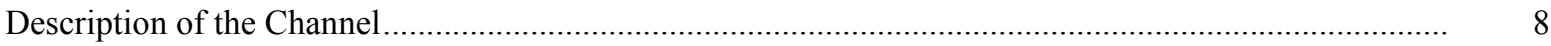

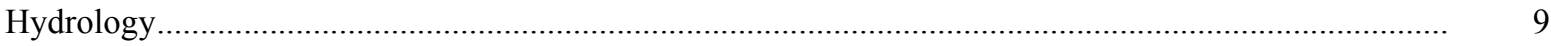

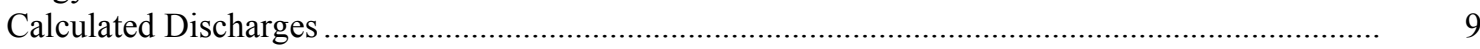

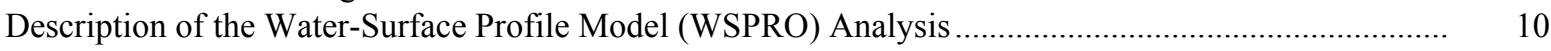

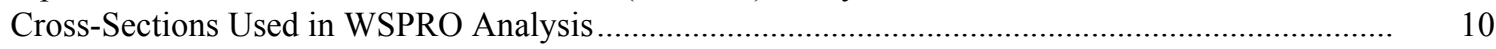

Data and Assumptions Used in WSPRO Model ..................................................................... 11

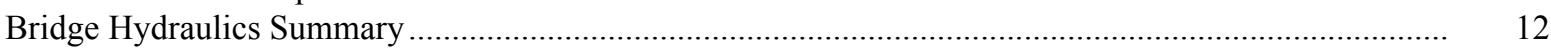

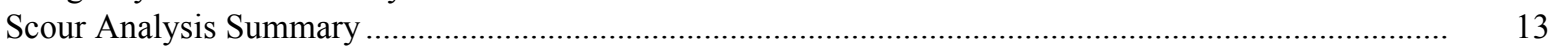

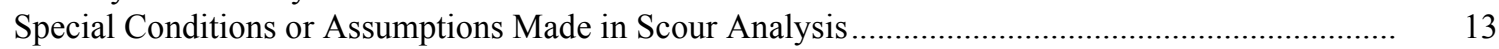

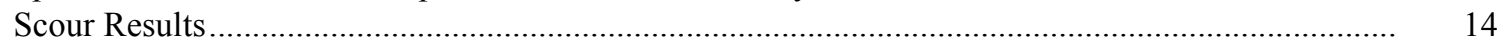

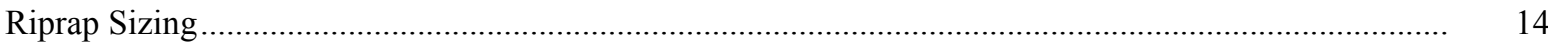

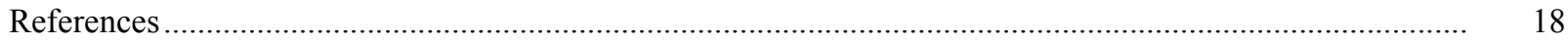

Appendixes:

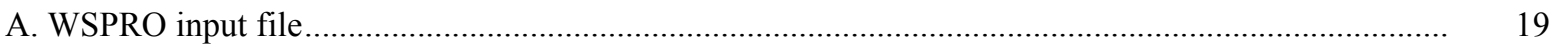

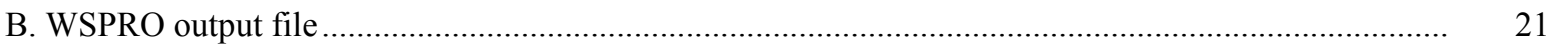

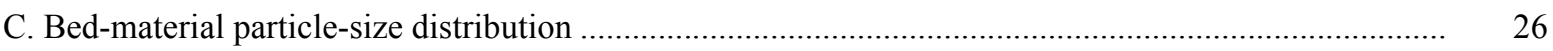

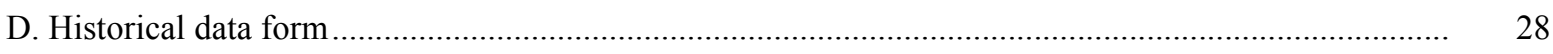

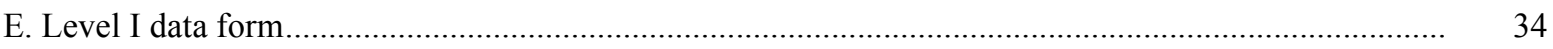

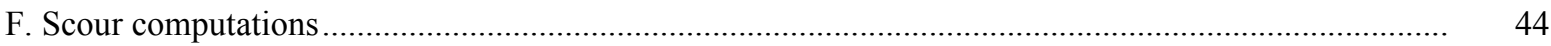

\section{FIGURES}

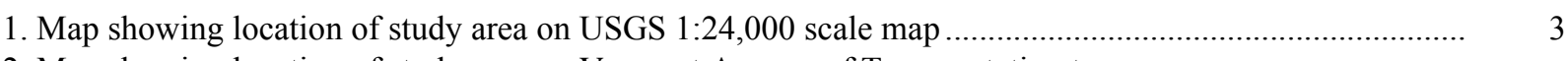

2. Map showing location of study area on Vermont Agency of Transportation town
highway map

3. Structure RICHTH00030006 viewed from upstream (June 28, 1995) ....................................................

4. Downstream channel viewed from structure RICHTH00030006 (June 28, 1995)............................... 5

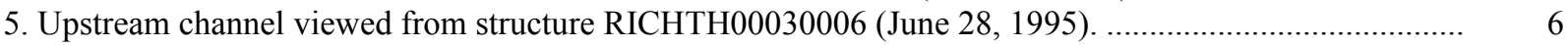

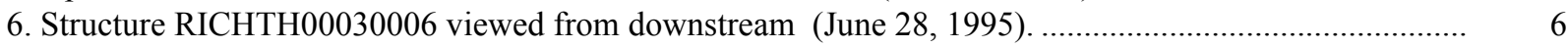

7. Water-surface profiles for the 100- and 500-year discharges at structure
RICHTH00030006 on Town Highway 3, crossing an unnamed tributary to the Missisquoi River, RICHFORD, Vermont.....

8. Scour elevations for the 100- and 500-year discharges at structure

RICHTH00030006 on Town Highway 3, crossing an unnamed tributary to the Missisquoi River, RICHFORD, Vermont.

\section{TABLES}

1. Remaining footing/pile depth at abutments for the 100-year discharge at structure

RICHTH00030006 on Town Highway 3, crossing an unnamed tributary to the Missisquoi River,

RICHFORD, Vermont

2. Remaining footing/pile depth at abutments for the 500-year discharge at structure

RICHTH00030006 on Town Highway 3, crossing an unnamed tributary to the Missisquoi River,

RICHFORD, Vermont

5




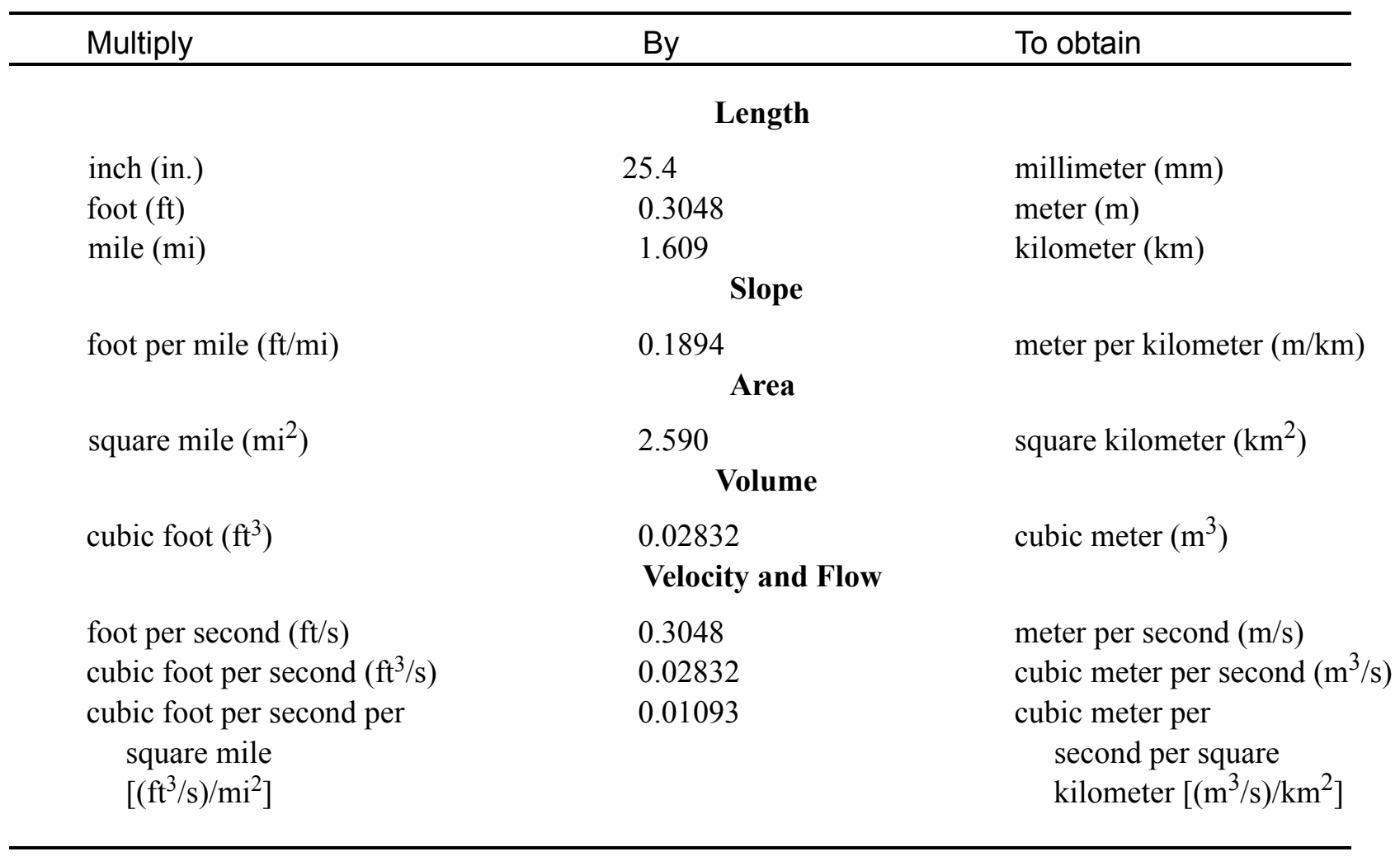

\section{OTHER ABBREVIATIONS}

$\begin{array}{lrlr}\mathrm{BF} & \text { bank full } & \text { LWW } & \text { left wingwall } \\ \mathrm{cfs} & \text { cubic feet per second } & \text { MC } & \text { main channel } \\ \mathrm{D}_{50} & \text { median diameter of bed material } & \text { RAB } & \text { right abutment } \\ \mathrm{DS} & \text { downstream } & \text { RABUT } & \text { face of right abutment } \\ \mathrm{elev} & \text { elevation } & \text { RB } & \text { right bank } \\ \mathrm{f} / \mathrm{p} & \text { flood plain } & \text { ROB } & \text { right overbank } \\ \mathrm{ft}^{2} & \text { square feet } & \text { RWW } & \text { right wingwall } \\ \mathrm{ft} / \mathrm{ft} & \text { feet per foot } & \text { TH } & \text { town highway } \\ \mathrm{JCT} & \text { junction } & \text { UB } & \text { under bridge } \\ \mathrm{LAB} & \text { left abutment } & \text { US } & \text { upstream } \\ \mathrm{LABUT} & \text { face of left abutment } & \text { USGS } & \text { United States Geological Survey } \\ \mathrm{LB} & \text { left bank } & \text { VTAOT Vermont Agency of Transportation } \\ \mathrm{LOB} & \text { left overbank } & \text { WSPRO } & \text { water-surface profile model }\end{array}$

In this report, the words "right" and "left" refer to directions that would be reported by an observer facing downstream. Sea level: In this report, "sea level" refers to the National Geodetic Vertical Datum of 1929-- a geodetic datum derived from a general adjustment of the first-order level nets of the United States and Canada, formerly called Sea Level Datum of 1929.

In the appendices, the above abbreviations may be combined. For example, USLB would represent upstream left bank. 


\title{
LEVEL II SCOUR ANALYSIS FOR BRIDGE 6 (RICHTH00030006) ON TOWN HIGHWAY 3, CROSSING AN UNNAMED TRIBUTARY TO THE MISSISQUOI RIVER, RICHFORD, VERMONT
}

\author{
By Robert H. Flynn and Donald L. Song \\ INTRODUCTION AND SUMMARY OF RESULTS
}

This report provides the results of a detailed Level II analysis of scour potential at structure RICHTH00030006 on Town Highway 3 crossing an unnamed tributary to the Missisquoi River, Richford, Vermont (figures 1-8). A Level II study is a basic engineering analysis of the site, including a quantitative analysis of stream stability and scour (U.S. Department of Transportation, 1993). Results of a Level I scour investigation also are included in Appendix E of this report. A Level I investigation provides a qualitative geomorphic characterization of the study site. Information on the bridge, gleaned from Vermont Agency of Transportation (VTAOT) files, was compiled prior to conducting Level I and Level II analyses and is found in Appendix D.

The site is in the Green Mountain section of the New England physiographic province of northern Vermont. The $4.5-\mathrm{mi}^{2}$ drainage area is in a predominantly rural basin. In the vicinity of the study site, the surface cover is pasture upstream and downstream of the bridge.

In the study area, the unnamed tributary to the Missisquoi River is a sinuous channel with a slope of approximately $0.008 \mathrm{ft} / \mathrm{ft}$, an average channel top width of $39 \mathrm{ft}$ and an average channel depth of $2 \mathrm{ft}$. The channel slope was obtained from a topographic map (USGS, 1986). The predominant channel bed material is gravel with a median grain size $\left(D_{50}\right)$ of $26.2 \mathrm{~mm}(0.0861 \mathrm{ft})$. The geomorphic assessment at the time of the Level I and Level II site visit on June 28, 1995, indicated that the reach was stable.

The Town Highway 3 crossing of an unnamed tributary to the Missisquoi River is a 26-ftlong, two-lane bridge consisting of one 24-foot concrete T-beam span (Vermont Agency of Transportation, written communication, March 9, 1995). The bridge is supported by vertical, concrete abutments with wingwalls. The channel is skewed approximately 40 degrees to the opening while the opening-skew-to-roadway is 0.0 degrees.

The only scour protection measures at the site were type- 2 stone fill (less than 36 inches diameter) along the upstream right wingwall and at the upstream end of the right abutment. Additional details describing conditions at the site are included in the Level II Summary and Appendices D and E. 
Scour depths and rock rip-rap sizes were computed using the general guidelines described in Hydraulic Engineering Circular 18 (Richardson and others, 1995). Total scour at a highway crossing is comprised of three components: 1) long-term streambed degradation; 2) contraction scour (due to accelerated flow caused by a reduction in flow area at a bridge) and; 3) local scour (caused by accelerated flow around piers and abutments). Total scour is the sum of the three components. Equations are available to compute depths for contraction and local scour and a summary of the results of these computations follows.

Contraction scour for all modelled flows ranged from 1.7 to $1.8 \mathrm{ft}$. The worst-case contraction scour occurred at the 500-year discharge. Scour at the left abutment ranged from 7.6 to $12.6 \mathrm{ft}$ with the worst case occurring at the 100 -year event. Scour at the right abutment ranged from 1.6 to $5.6 \mathrm{ft}$ with the worst case occurring at the 500 -year event. Additional information on scour depths and depths to armoring are included in the section titled "Scour Results". Scoured-streambed elevations, based on the calculated scour depths, are presented in tables 1 and 2. A cross-section of the scour computed at the bridge is presented in figure 8 . Scour depths were calculated assuming an infinite depth of erosive material and a homogeneous particle-size distribution.

It is generally accepted that the Froehlich equation (abutment scour) gives "excessively conservative estimates of scour depths" (Richardson and others, 1995, p. 47). Usually, computed scour depths are evaluated in combination with other information including (but not limited to) historical performance during flood events, the geomorphic stability assessment, existing scour protection measures, and the results of the hydraulic analyses. Therefore, scour depths adopted by VTAOT may differ from the computed values documented herein. 


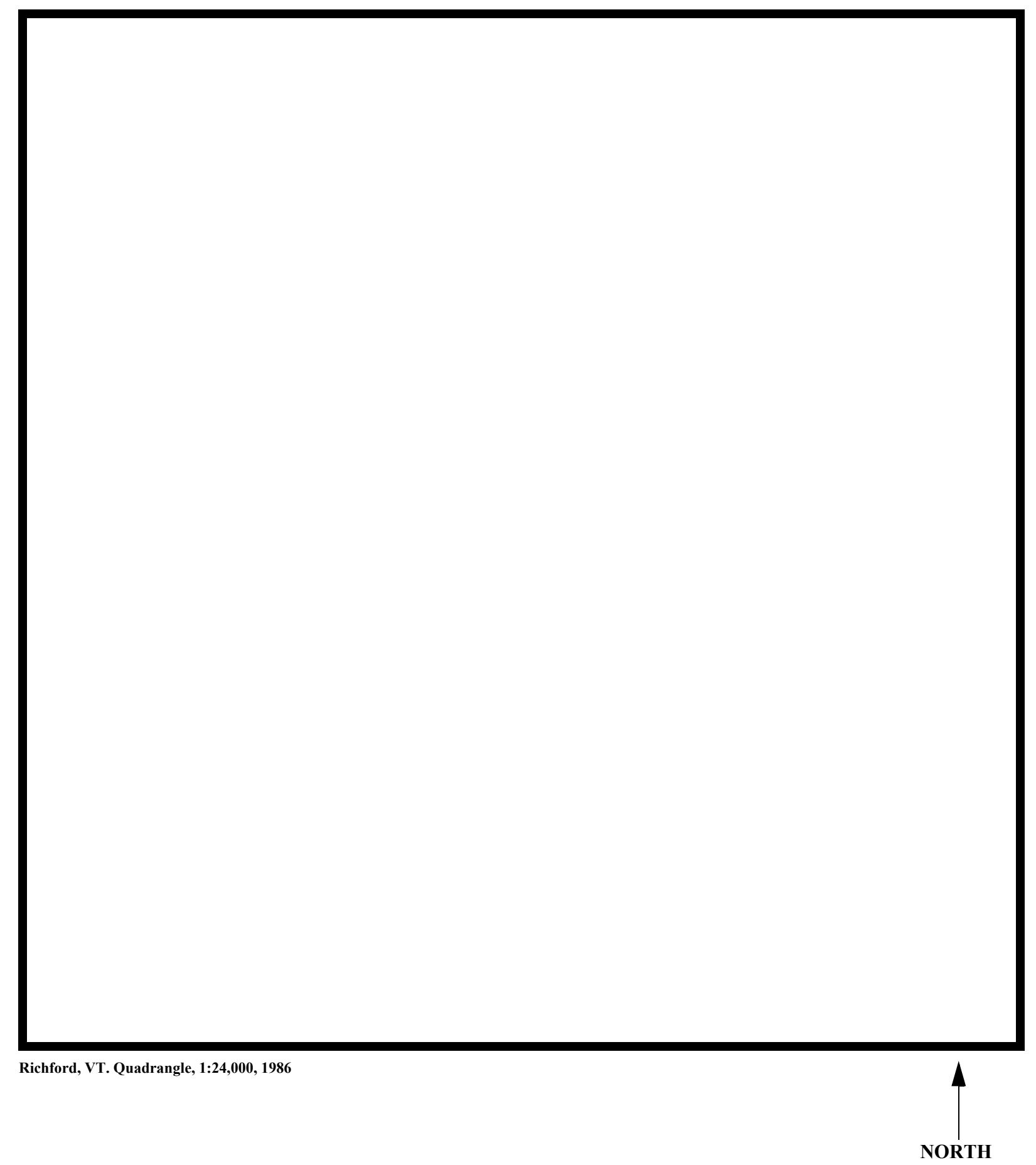

Figure 1. Location of study area on USGS 1:24,000 scale map. 
Figure 2. Location of study area on Vermont Agency of Transportation town highway map. 

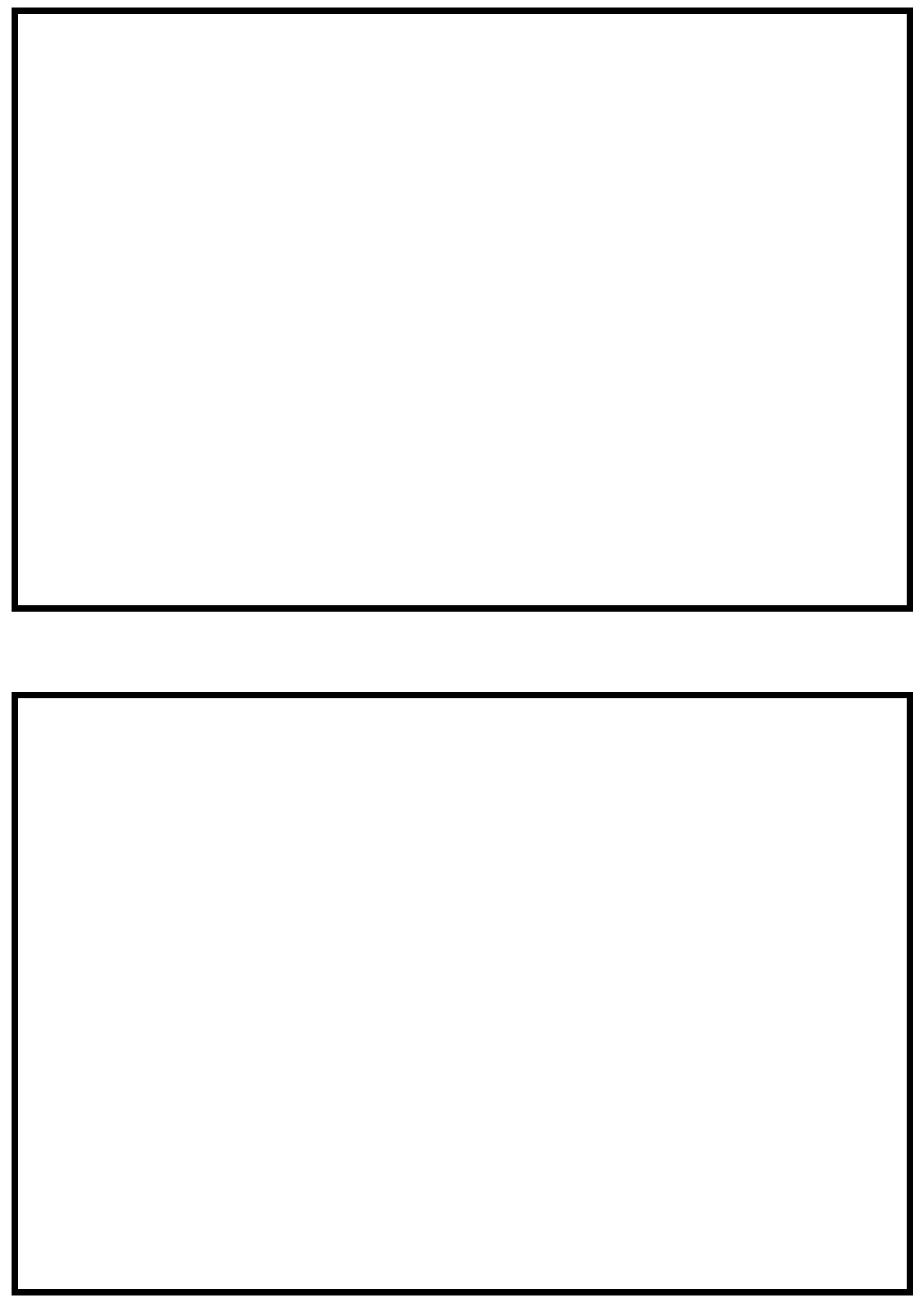

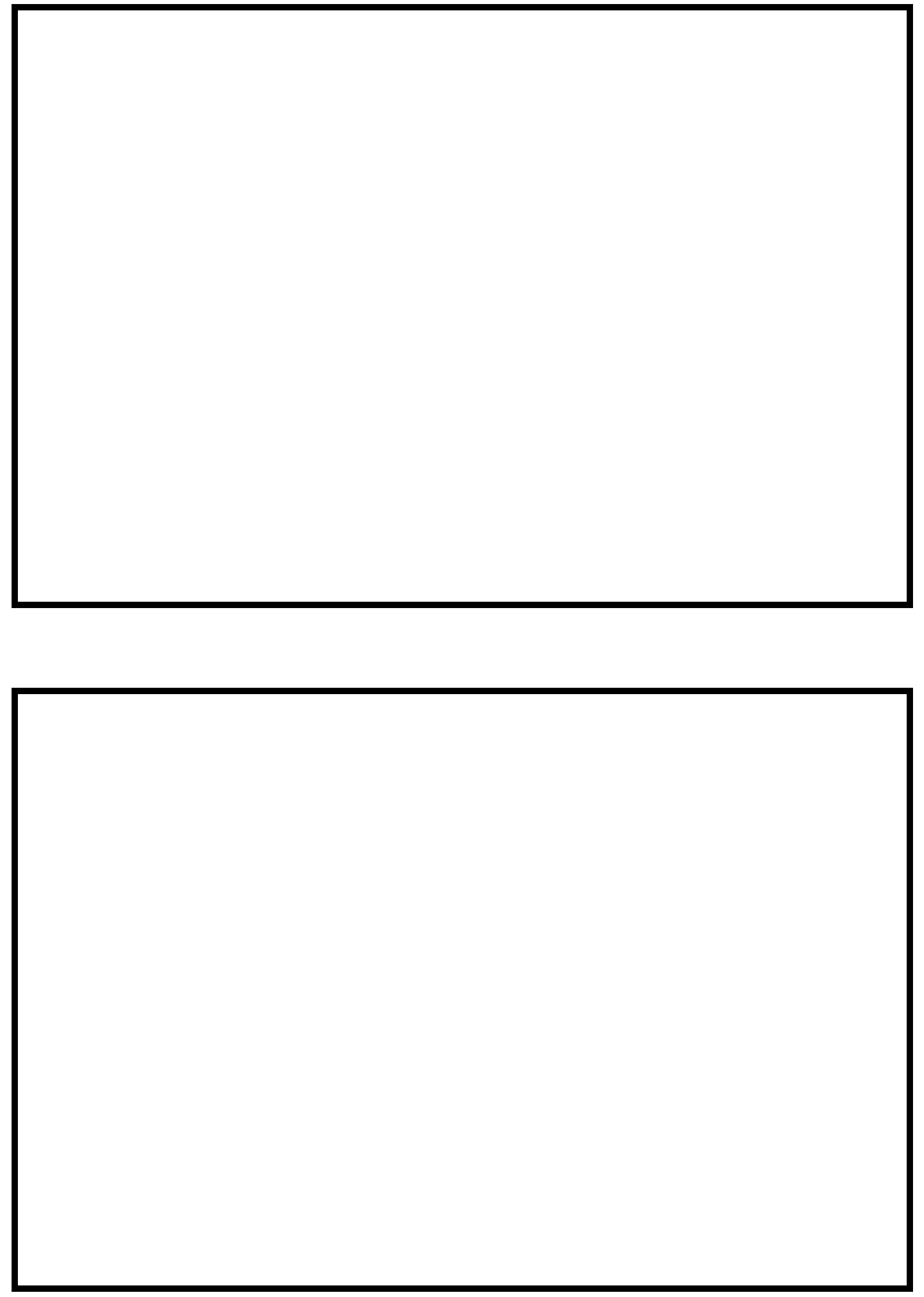


\section{LEVEL II SUMMARY}

\begin{tabular}{llllll} 
& Structure Number & RICHTH00030006 & & \multicolumn{3}{c}{ Unnamed trib. to Missisquoi Riv. } \\
& Stream & & & \\
County & Franklin & Road & TH3 & District & 8
\end{tabular}

\section{Description of Bridge}

Bridge length $\frac{26}{2} f \quad$ Bridge width $\stackrel{23.4}{f} \quad$ Max span length $\stackrel{24}{f t}$ Alignment of bridge to road (on curve or straight)

Abutment type Vertical, concrete

Stone fill on abutment?

$$
\text { Yes }
$$

\section{Embankment type} Straight

right wingwall in good condition.

Abutments and wingwalls are concrete. The footing of

both abutments are exposed. The right abutment has a subfooting.

\section{Y}

Is bridge skewed to flood flow according to Y Y survey?

Angle

There is a mild_channel bend in the upstream and downstream reach.

Debris accumulation on bridge at time of Level I or Level II site visit:

$$
\begin{aligned}
& \text { Date of incnortion } \\
& 06 / 28 / 95 \\
& \hline
\end{aligned}
$$

Level I

$06 / 28 / 95$

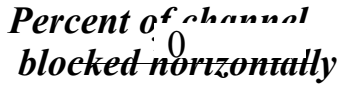

0

\section{Percent of allo...nel blocked verticatty}

0

Level II

Low. There is no debris accumulation although there is a slight constriction of the channel due to the bridge.

Potential for debris

Doscriho any, foaturos noar ar at tho hridos that mav, affoct flou, (includo ahsorvation dato) 


\section{Description of the Geomorphic Setting}

General topography The channel is located within a low relief valley setting with an irregular flood plain.

Geomorphic conditions at bridge site: downstream (DS), upstream (US)

Date of inspection $\quad 06 / 28 / 95$

DS left: $\quad$ Moderately sloping channel bank to a wide terrace

DS right: $\quad$ Low sloping channel bank to flood plain

US left: $\quad$ Low sloping channel bank to flood plain

US right: $\quad$ Moderately sloping channel bank to a wide terrace

\section{Description of the Channel}

\begin{tabular}{|c|c|c|c|}
\hline \multirow[b]{2}{*}{ Average top width } & 39 & \multirow[b]{2}{*}{ Average depth } & \multirow[b]{2}{*}{ Sand / Gravel } \\
\hline & $\begin{array}{c}\boldsymbol{f +} \\
\text { Gravel }\end{array}$ & & \\
\hline Predominant bed $m$ & & Bank material & Meandering but \\
\hline
\end{tabular}

stable with alluvial channel boundaries and an irregular flood plain."

$06 / 28 / 95$

Vegetative co 1 Pasture

DS left: $\quad$ Pasture

DS right: Pasture

US left: $\quad$ Pasture.

US right: $\quad \underline{\mathrm{Y}}$

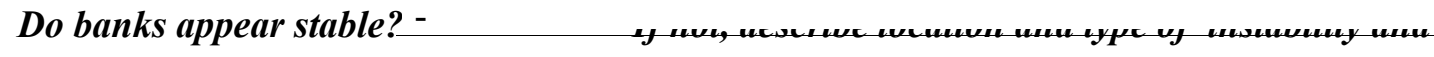

date of observation.

Describe any obstructions in channel and date of observation. 


\section{Hydrology}

Drainage area $\quad 4.5 \quad \boldsymbol{m i}^{2}$

Percentage of drainage area in physiographic provinces: (approximate)

Physiographic province/section

New England / Green Mountain
Percent of drainage area 100

Is drainage area considered rural or urban? Rural Describe any significant urbanization:

Is there a USGS gage on the stream of interest?

No

$--$

\section{USGS gage description}

USGS gage number

Gage drainage area $\mathrm{mi}^{2}$

No

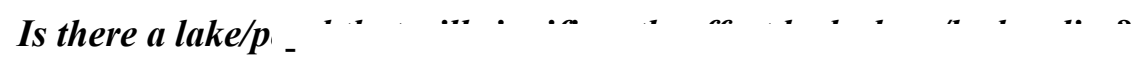

\section{Calculated Discharges 1080}

Q100 $\quad \mathrm{ft}^{3} / \mathrm{s} \quad \mathrm{Q500} \quad \mathrm{ft} / \mathrm{s}$

The 100- and 500-year discharges are based on

the median of discharge frequency curves which were developed from empirical relationships and extended to the 500-year discharge (Benson, 1962; Johnson and Tasker, 1974; FHWA, 1983; Potter, 1957a\&b; Talbot, 1887). 


\section{Description of the Water-Surface Profile Model (WSPRO) Analysis}

Datum for WSPRO analysis (USGS survey, sea level, VTAOT plans)

USGS survey

Datum tie between USGS survey and VTAOT plans

None

Description of reference marks used to determine USGS datum. $\quad$ RM1 is a chiseled " $\mathrm{X}$ "

on top of the right end of the downstream bridge rail (elev. $501.73 \mathrm{ft}$, arbitrary survey datum).

RM2 is a chiseled " $\mathrm{X}$ "on top of the upstream end of the upstream left wingwall (elev. 495.19

$\mathrm{ft}$, arbitrary survey datum).

\section{Cross-Sections Used in WSPRO Analysis}

\begin{tabular}{cccl}
\hline${ }^{1}$ Cross-section & $\begin{array}{c}\text { Section } \\
\text { Reference } \\
\text { Distance } \\
(\text { SRD) } \text { in feet }\end{array}$ & $\begin{array}{c}{ }^{2} \text { Cross-section } \\
\text { development }\end{array}$ & \multicolumn{1}{c}{ Comments } \\
\hline EXITX & -26 & 1 & Exit section \\
\hline FULLV & 0 & 2 & $\begin{array}{l}\text { Downstream Full-valley } \\
\text { section (Templated from } \\
\text { EXITX) }\end{array}$ \\
\hline BRIDG & 0 & 1 & Bridge section \\
\hline RDWAY & 12 & 1 & \begin{tabular}{l} 
Road Grade section \\
\hline APPRO
\end{tabular} \\
\hline APTEM & 45 & 2 & $\begin{array}{l}\text { Modelled Approach sec- } \\
\text { tion (Templated from } \\
\text { APTEM) }\end{array}$ \\
\hline
\end{tabular}

${ }^{1}$ For location of cross-sections see plan-view sketch included with Level I field form, Appendix E.

For more detail on how cross-sections were developed see WSPRO input file. 


\section{Data and Assumptions Used in WSPRO Model}

Hydraulic analyses of the reach were done by use of the Federal Highway Administration's WSPRO step-backwater computer program (Shearman and others, 1986, and Shearman, 1990). The analyses reported herein reflect conditions existing at the site at the time of the study. Furthermore, in the development of the model it was necessary to assume no accumulation of debris or ice at the site. Results of the hydraulic model are presented in the Bridge Hydraulic Summary, Appendix B, and figure 7.

Channel roughness factors (Manning's " $n$ ") used in the hydraulic model were estimated using field inspections at each cross section following the general guidelines described by Arcement and Schneider (1989). Final adjustments to the values were made during the modelling of the reach. Channel " $n$ " values for the reach ranged from 0.033 to 0.037 , and overbank " $n$ " values ranged from 0.037 to 0.043 .

This unnamed tributary drains into the Missisquoi River approximately 600 feet downstream of the bridge. The close proximity of the confluence may affect the hydraulics at this bridge site, especially if the flow peaks are simultaneous. However an analysis of potential backwater from the Missisquoi River is outside of the scope of this study and normal depth at the exit section (EXITX) was assumed as the starting water surface. This depth was computed by use of the slope-conveyance method outlined in the User's manual for WSPRO (Shearman, 1990). The slope used was $0.0082 \mathrm{ft} / \mathrm{ft}$ which was estimated from the topographic map (U.S. Geological Survey, 1986).

The surveyed approach section (APTEM) was moved along the approach channel slope $(0.0082 \mathrm{ft} / \mathrm{ft})$ to establish the modelled approach section (APPRO), one bridge length upstream of the upstream face as recommended by Shearman and others (1986). This approach also provides a consistent method for determining scour variables.

For the 100-year discharge, WSPRO assumes critical depth at the bridge section. A supercritical model was developed for this discharge. Analyzing both the supercritical and subcritical profiles, it can be determined that the water surface profile passes through critical depth within the bridge opening for the 100-year discharge. Thus, the assumption of critical depth is a satisfactory solution for the 100 -year discharge. 


\section{Bridge Hydraulics Summary}

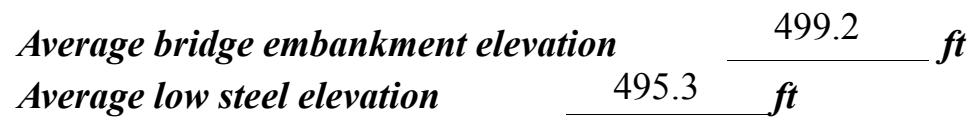

100-year discharge $\quad 785 \quad \mathrm{ft}^{3} / \mathrm{s}$

Water-surface elevation in bridge opening

$492.5 f t$

Road overtopping? ___ N Discharge over road ___

Area of flow in bridge opening $\quad 73.8 \quad \mathrm{ft}^{2}$

Average velocity in bridge opening $10.6 \mathrm{ft} / \mathrm{s}$

$\begin{array}{llll}\text { Maximum WSPRO tube velocity at bridge } & 12.9 \mathrm{ft} / \mathrm{s}\end{array}$

Water-surface elevation at Approach section with bridge 494.7

Water-surface elevation at Approach section without bridge $\quad 492.8$

Amount of backwater caused by bridge $\quad 1.9$ it

500-year discharge $\quad \begin{array}{ll}1080 & \mathrm{ft}^{3} / \mathrm{s}\end{array}$

Water-surface elevation in bridge opening

$495.6 f t$

Road overtopping? ___ N Discharge over road

Area of flow in bridge opening $\quad 132.4 \quad \mathrm{ft}^{2}$

Average velocity in bridge opening $8.2 \mathrm{ft} / \mathrm{s}$

Maximum WSPRO tube velocity at bridge 9.8 's

Water-surface elevation at Approach section with bridge 496.9

Water-surface elevation at Approach section without bridge $\quad 493.5$

Amount of backwater caused by bridge $\quad 3.4$.

Incipient overtopping discharge ___ _ $\quad f^{3} / \mathrm{s}$

Water-surface elevation in bridge opening $\quad-\quad t$

Area of flow in bridge opening _ _ _ $\mathrm{ft}^{2}$

Average velocity in bridge opening ___ $\quad \mathrm{ft} / \mathrm{s}$

Maximum WSPRO tube velocity at bridge _ $\quad-\quad f t / s$

Water-surface elevation at Approach section with bridge

Water-surface elevation at Approach section without bridge

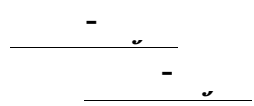

Amount of backwater caused by bridge _ _ _ t 


\section{Scour Analysis Summary}

\section{Special Conditions or Assumptions Made in Scour Analysis}

Scour depths were computed using the general guidelines described in Hydraulic Engineering Circular 18 (Richardson and others, 1995). Scour depths were calculated assuming an infinite depth of erosive material and a homogeneous particle-size distribution. The results of the scour analysis are presented in tables 1 and 2 and a graph of the scour depths is presented in figure 8 .

Contraction scour for the 100-year discharge was computed by use of Laursen's clear-water contraction scour equation (Richardson and others, 1995, p. 32, equation 20). The 500-year discharge resulted in unsubmerged pressure flow. Contraction scour at bridges with orifice flow is best estimated by use of the Chang pressure-flow scour equation (oral communication, J. Sterling Jones, October 4, 1996). Contraction scour for the 500-year event was computed by the Chang pressure flow scour equation (Richardson and others, 1995, p. 145-146). The results of Laursen's clear-water contraction scour for the 500-year event were also computed and can be found in appendix F.

Abutment scour at the left abutment for the 100-year discharge was computed by use of the Froehlich equation (Richardson and others, 1995, p. 48, equation 28). Variables for the Froehlich equation include the Froude number of the flow approaching the embankments, the length of the embankment blocking flow, and the depth of flow approaching the embankment less any roadway overopping.

Scour at the right abutment for the 100- and 500-year discharges and the left abutment for the 500-year discharge was computed by use of the HIRE equation (Richardson and others, 1995, p. 49, equation 29) because the HIRE equation is recommended when the length to depth ratio of the embankment blocking flow exceeds 25 . The variables used by the HIRE abutment-scour equation are defined the same as those defined for the Froehlich abutment-scour equation. 


\section{Scour Results}

\section{0-yr discharge 500-yr discharge}

Contraction scour:

(Scour depths in feet)

Main channel

Live-bed scour

Clear-water scour

Depth to armoring

Left overbank

Right overbank

Local scour:

Abutment scour

Left abutment

Right abutment

Pier scour

Pier 1

Pier 2

Pier 3

12.6

$1.6-$
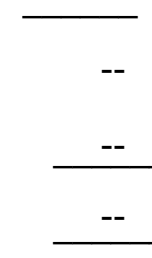

7.6

$5.6-$
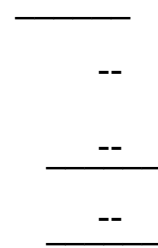

Incipient overtopping discharge 


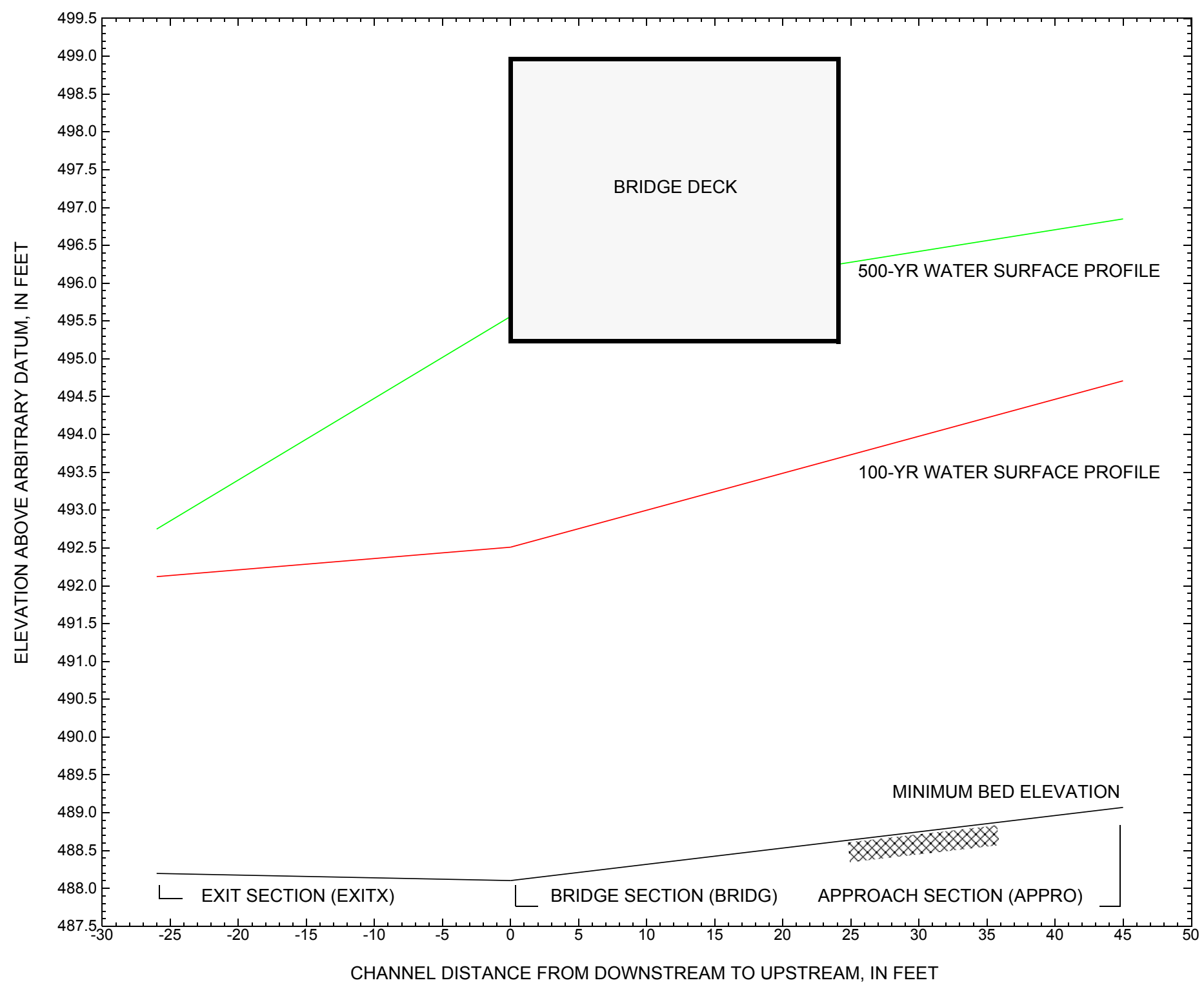

Figure 7. Water-surface profiles for the 100- and 500-yr discharges at structure RICHTH00030006 on Town Highway 34, crossing an unnamed tributary to the Missisquoi River, Richford, Vermont. 


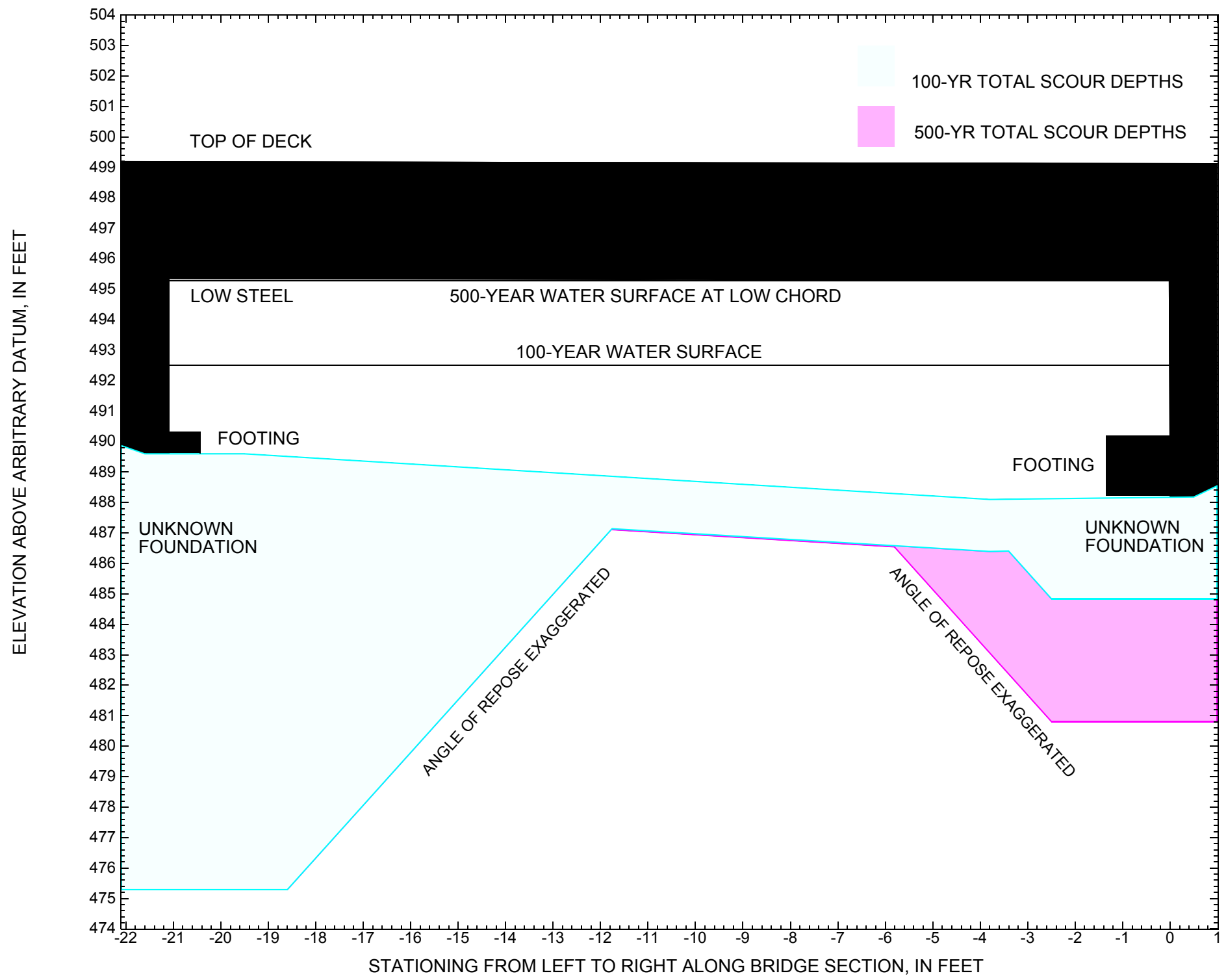

Figure 8. Scour elevations for the 100-yr and 500-yr discharges at structure RICHTH00030006 on Town Highway 34, crossing an unnamed tributary to the Missisquoi River, Richford, Vermont. 


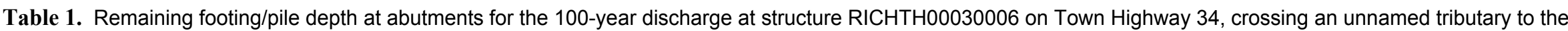
Missisquoi River, Richford, Vermont.

[VTAOT, Vermont Agency of Transportation; --,no data]

\begin{tabular}{|c|c|c|c|c|c|c|c|c|c|c|c|}
\hline Description & Station $^{1}$ & $\begin{array}{l}\text { VTAOT } \\
\text { minimum } \\
\text { low-chord } \\
\text { elevation } \\
\text { (feet) }\end{array}$ & $\begin{array}{l}\text { Surveyed } \\
\text { minimum } \\
\text { low-chord } \\
\text { elevation }{ }^{2} \\
\text { (feet) }\end{array}$ & $\begin{array}{c}\text { Bottom of } \\
\text { footing } \\
\text { elevation } \\
\text { (feet) }\end{array}$ & $\begin{array}{l}\text { Channel } \\
\text { elevation at } \\
\text { abutment/ } \\
\text { pier }^{2} \\
\text { (feet) }\end{array}$ & $\begin{array}{l}\text { Contraction } \\
\text { scour depth } \\
\text { (feet) }\end{array}$ & $\begin{array}{l}\text { Abutment } \\
\text { scour } \\
\text { depth } \\
\text { (feet) }\end{array}$ & $\begin{array}{l}\text { Pier } \\
\text { scour } \\
\text { depth } \\
\text { (feet) }\end{array}$ & $\begin{array}{l}\text { Depth of } \\
\text { total scour } \\
\text { (feet) }\end{array}$ & $\begin{array}{c}\text { Elevation of } \\
\text { scour }^{2} \\
\text { (feet) }\end{array}$ & $\begin{array}{c}\text { Remaining } \\
\text { footing/pile } \\
\text { depth } \\
\text { (feet) }\end{array}$ \\
\hline \multicolumn{12}{|c|}{100 -yr. discharge is 785 cubic-feet per second } \\
\hline Left abutment & -21.1 & -- & 495.1 & -- & 489.6 & 1.7 & 12.6 & -- & 14.3 & 475.3 & -- \\
\hline Right abutment & 0.0 & -- & 495.6 & -- & 488.2 & 1.7 & 1.6 & -- & 3.3 & 484.9 & -- \\
\hline
\end{tabular}

1.Measured along the face of the most constricting side of the bridge.

2.Arbitrary datum for this study.

Table 2. Remaining footing/pile depth at abutments for the 500-year discharge at structure RICHTH00030006 on Town Highway 34, crossing an unnamed tributary to the Missisquoi River, Richford, Vermont.

[VTAOT, Vermont Agency of Transportation; --, no data]

\begin{tabular}{|c|c|c|c|c|c|c|c|c|c|c|c|}
\hline Description & Station $^{1}$ & $\begin{array}{l}\text { VTAOT } \\
\text { minimum } \\
\text { low-chord } \\
\text { elevation } \\
\text { (feet) }\end{array}$ & $\begin{array}{c}\text { Surveyed } \\
\text { minimum } \\
\text { low-chord } \\
\text { elevation } \\
\text { (feet) }\end{array}$ & $\begin{array}{l}\text { Bottom of } \\
\text { footing } \\
\text { elevation } \\
\text { (feet) }\end{array}$ & $\begin{array}{c}\text { Channel } \\
\text { elevation at } \\
\text { abutment/ } \\
\text { pier }^{2} \\
\text { (feet) }\end{array}$ & $\begin{array}{l}\text { Contraction } \\
\text { scour depth } \\
\text { (feet) }\end{array}$ & $\begin{array}{l}\text { Abutment } \\
\text { scour } \\
\text { depth } \\
\text { (feet) }\end{array}$ & $\begin{array}{l}\text { Pier } \\
\text { scour } \\
\text { depth } \\
\text { (feet) }\end{array}$ & $\begin{array}{l}\text { Depth of } \\
\text { total scour } \\
\text { (feet) }\end{array}$ & $\begin{array}{c}\text { Elevation of } \\
\text { scour }^{2} \\
\text { (feet) }\end{array}$ & $\begin{array}{c}\text { Remaining } \\
\text { footing/pile } \\
\text { depth } \\
\text { (feet) }\end{array}$ \\
\hline \multicolumn{12}{|c|}{500 -yr. discharge is 1,080 cubic-feet per second } \\
\hline Left abutment & -21.1 & -- & 495.1 & -- & 489.6 & 1.8 & 7.6 & -- & 9.4 & 480.2 & -- \\
\hline Right abutment & 0.0 & -- & 495.6 & -- & 488.2 & 1.8 & 5.6 & -- & 7.4 & 480.8 & -- \\
\hline
\end{tabular}

1.Measured along the face of the most constricting side of the bridge.

2.Arbitrary datum for this study. 


\section{SELECTED REFERENCES}

Arcement, G.J., Jr., and Schneider, V.R., 1989, Guide for selecting Manning's roughness coefficients for natural channels and flood plains: U.S. Geological Survey Water-Supply Paper 2339, 38 p.

Barnes, H.H., Jr., 1967, Roughness characteristics of natural channels: U.S. Geological Survey Water-Supply Paper 1849,213 p.

Benson, M. A., 1962, Factors Influencing the Occurrence of Floods in a Humid Region of Diverse Terrain: U.S. Geological Survey WaterSupply Paper 1580-B, 64 p.

Brown, S.A. and Clyde, E.S., 1989, Design of riprap revetment: Federal Highway Administration Hydraulic Engineering Circular No. 11, Publication FHWA-IP-89-016, 156 p.

Federal Highway Administration, 1983, Runoff estimates for small watersheds and development of sound design: Federal Highway Administration Report FHWA-RD-77-158

Froehlich, D.C., 1989, Local scour at bridge abutments in Ports, M.A., ed., Hydraulic Engineering--Proceedings of the 1989 National Conference on Hydraulic Engineering: New York, American Society of Civil Engineers, p. 13-18.

Hayes, D.C.,1993, Site selection and collection of bridge-scour data in Delaware, Maryland, and Virginia: U.S. Geological Survey WaterResources Investigation Report 93-4017, 23 p.

Interagency Advisory Committee on Water Data, 1982, Guidelines for determining flood flow frequency: U.S. Geological Survey, Bulletin 17B of the Hydrology Subcommittee, 190 p.

Johnson, C.G. and Tasker, G.D.,1974, Progress report on flood magnitude and frequency of Vermont streams: U.S. Geological Survey OpenFile Report 74-130, 37 p.

Lagasse, P.F., Schall, J.D., Johnson, F., Richardson, E.V., Chang, F., 1995, Stream Stability at Highway Structures: Federal Highway Administration Hydraulic Engineering Circular No. 20, Publication FHWA-IP-90-014, 144 p.

Laursen, E.M., 1960, Scour at bridge crossings: Journal of the Hydraulics Division, American Society of Civil Engineers, v. 86, no. HY2, p. 39-53.

Potter, W. D., 1957a, Peak rates of runoff in the Adirondack, White Mountains, and Maine woods area, Bureau of Public Roads

Potter, W. D., 1957b, Peak rates of runoff in the New England Hill and Lowland area, Bureau of Public Roads

Richardson, E.V. and Davis, S.R., 1995, Evaluating scour at bridges: Federal Highway Administration Hydraulic Engineering Circular No. 18, Publication FHWA-IP-90-017, 204 p.

Richardson, E.V., Simons, D.B., and Julien, P.Y., 1990, Highways in the river environment: Federal Highway Administration Publication FHWA-HI-90-016.

Ritter, D.F., 1984, Process Geomorphology: W.C. Brown Co., Debuque, Iowa, 603 p.

Shearman, J.O., 1990, User's manual for WSPRO--a computer model for water surface profile computations: Federal Highway Administration Publication FHWA-IP-89-027, 187 p.

Shearman, J.O., Kirby, W.H., Schneider, V.R., and Flippo, H.N., 1986, Bridge waterways analysis model; research report: Federal Highway Administration Publication FHWA-RD-86-108, 112 p.

Talbot, A.N., 1887, The determination of water-way for bridges and culverts.

U.S. Department of Transportation, 1993, Stream stability and scour at highway bridges, Participant Workbook: Federal Highway Administration Publication FHWA HI-91-011.

U.S. Geological Survey, 1986, Richford, Vermont 7.5 Minute Series quadrangle map: U.S. Geological Survey Topographic Maps, Scale $1: 24,000$. 


\section{APPENDIX A: \\ WSPRO INPUT FILE}




\section{WSPRO INPUT FILE}

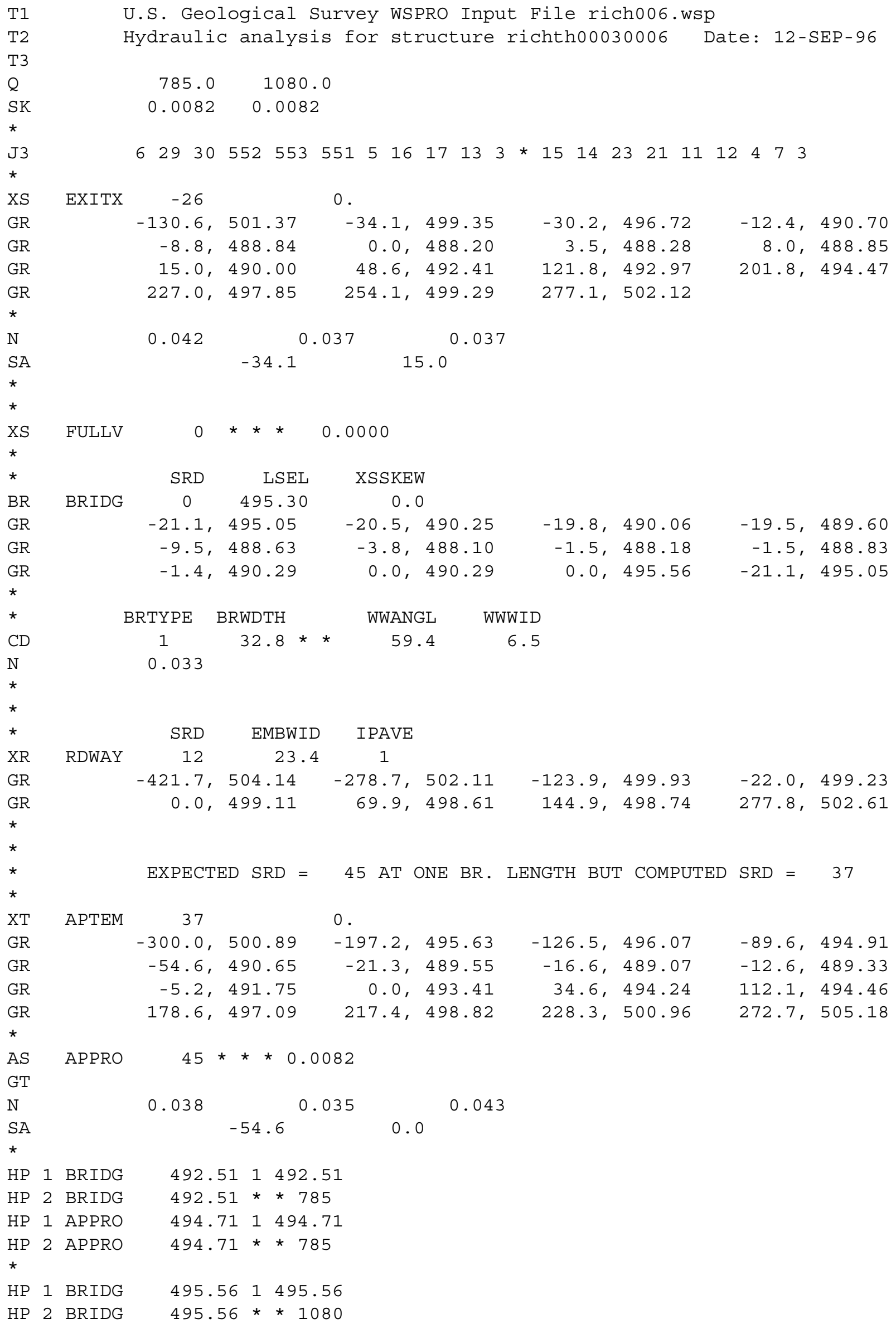




\section{APPENDIX B: \\ WSPRO OUTPUT FILE}


WSPRO OUTPUT FILE (continued)

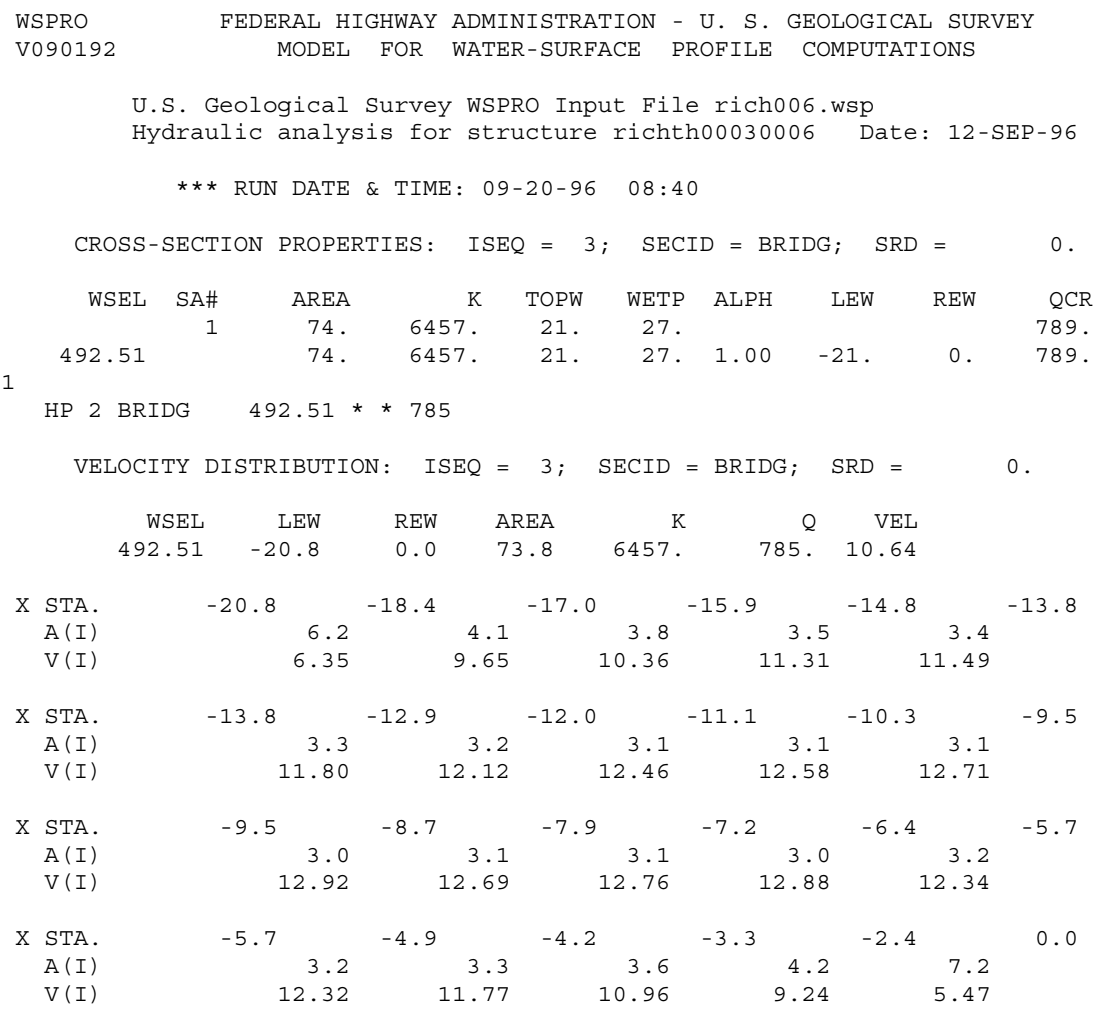

CROSS-SECTION PROPERTIES: $\quad$ ISEQ $=5 ; \quad$ SECID $=$ APPRO; $\quad$ SRD $=$

\begin{tabular}{|c|c|c|c|c|c|c|c|c|c|}
\hline WSEL & SA\# & AREA & K & TOPW & WETP & ALPH & LEW & REW & QCR \\
\hline & 1 & 66. & 4056 & 33. & 33. & & & & 526. \\
\hline & 2 & 239. & 27051 . & 55. & 55. & & & & 2843. \\
\hline & 3 & 52. & 1037. & 117. & 117. & & & & 195. \\
\hline
\end{tabular}

VELOCITY DISTRIBUTION : ISEQ $=5 ; \quad \operatorname{SECID}=\operatorname{APPRO} ; \quad \operatorname{SRD}=45$.

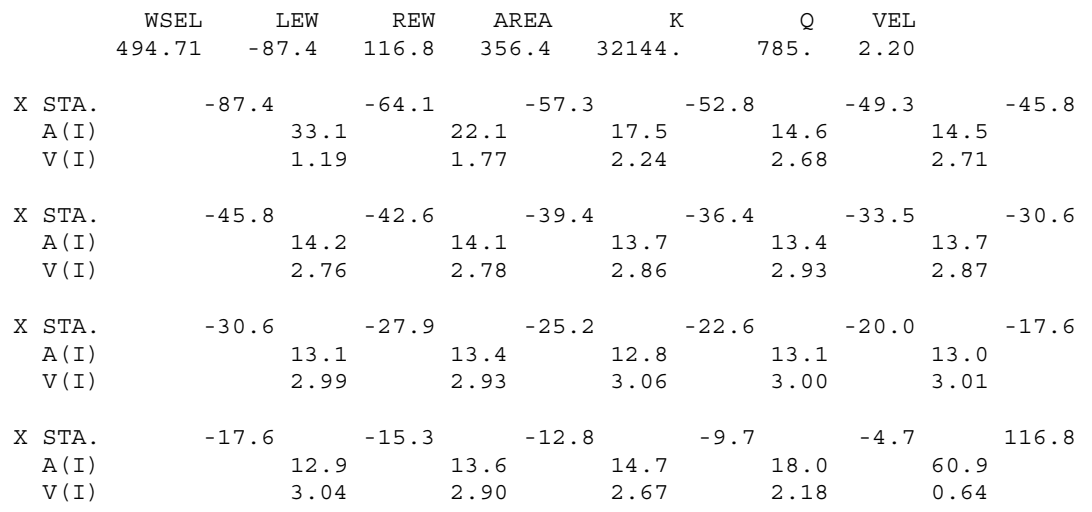


WSPRO OUTPUT FILE (continued)

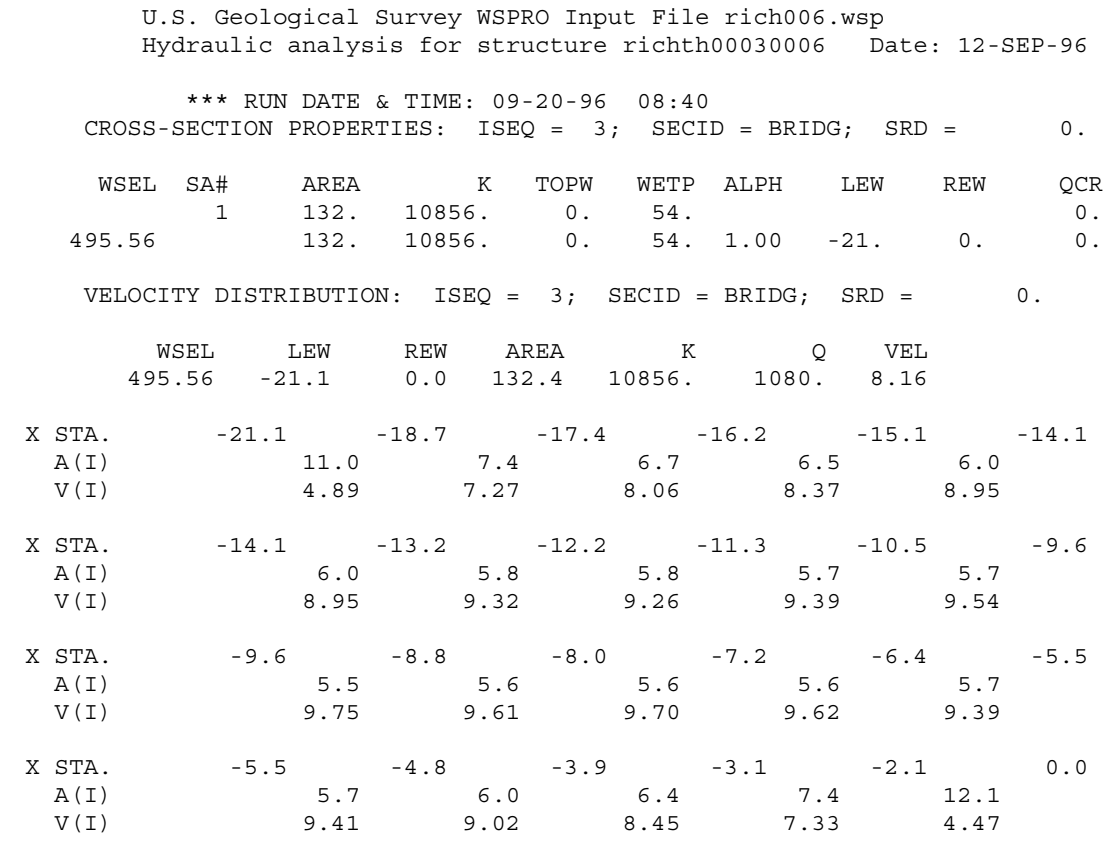

U.S. Geological Survey WSPRO Input File rich006.wsp

Hydraulic analysis for structure richth00030006 Date: 12-SEP-96

$* * *$ RUN DATE \& TIME: 09-20-96 08:40

CROSS-SECTION PROPERTIES: ISEQ = 5; SECID = APPRO; $\quad$ SRD = 45 .

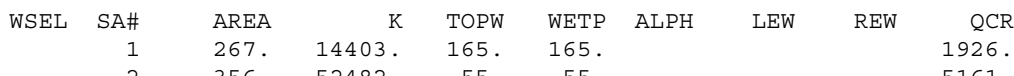

$\begin{array}{rrrrrr}2 & 356 . & 52482 . & 55 . & 55 . & 5161 . \\ 3 & 359 . & 20436 . & 171 . & 171 . & 2957 .\end{array}$

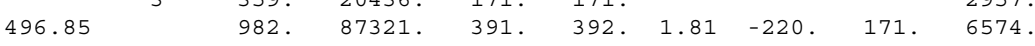

VELOCITY DISTRIBUTION: ISEQ $=5 ;$ SECID $=$ APPRO $; \quad$ SRD $=45$.

\begin{tabular}{|c|c|c|c|c|c|c|c|c|}
\hline & & WSEL & REW & AREA & $\mathrm{K}$ & $Q$ & VEL & \\
\hline & & 496.85 & 170.9 & 982.5 & 87321. & 1080. & 1.10 & \\
\hline \multirow[t]{3}{*}{$X$} & STA. & -219.8 & -93.5 & -67.9 & & -57.2 & -51.2 & -46.4 \\
\hline & $A(I)$ & 119.7 & & 76.6 & 55.3 & 36.7 & 30.3 & \\
\hline & $V(I)$ & 0.45 & & 0.71 & 0.98 & 1.47 & 1.78 & \\
\hline \multirow[t]{3}{*}{$\mathrm{X}$} & STA. & -46.4 & -41.9 & -37.4 & & -33.2 & -29.2 & -25.1 \\
\hline & $A(I)$ & 29.1 & & 29.6 & 28.7 & 27.9 & 28.5 & \\
\hline & $V(I)$ & 1.86 & & 1.83 & 1.88 & 1.93 & 1.90 & \\
\hline \multirow[t]{3}{*}{$\mathrm{x}$} & STA. & -25.1 & -21.3 & -17.5 & & -14.0 & -9.9 & -3.7 \\
\hline & $A(I)$ & 27.5 & & 27.6 & 27.2 & 29.5 & 34.4 & \\
\hline & $V(I)$ & 1.96 & & 1.95 & 1.98 & 1.83 & 1.57 & \\
\hline & STA. & -3.7 & 13.0 & 37.4 & & 65.8 & 97.4 & 170.9 \\
\hline & $A(I)$ & 56.4 & & 67.7 & 70.9 & 76.1 & 102.8 & \\
\hline & $V(I)$ & 0.96 & & 0.80 & 0.76 & 0.71 & 0.53 & \\
\hline
\end{tabular}




\section{WSPRO OUTPUT FILE (continued)}

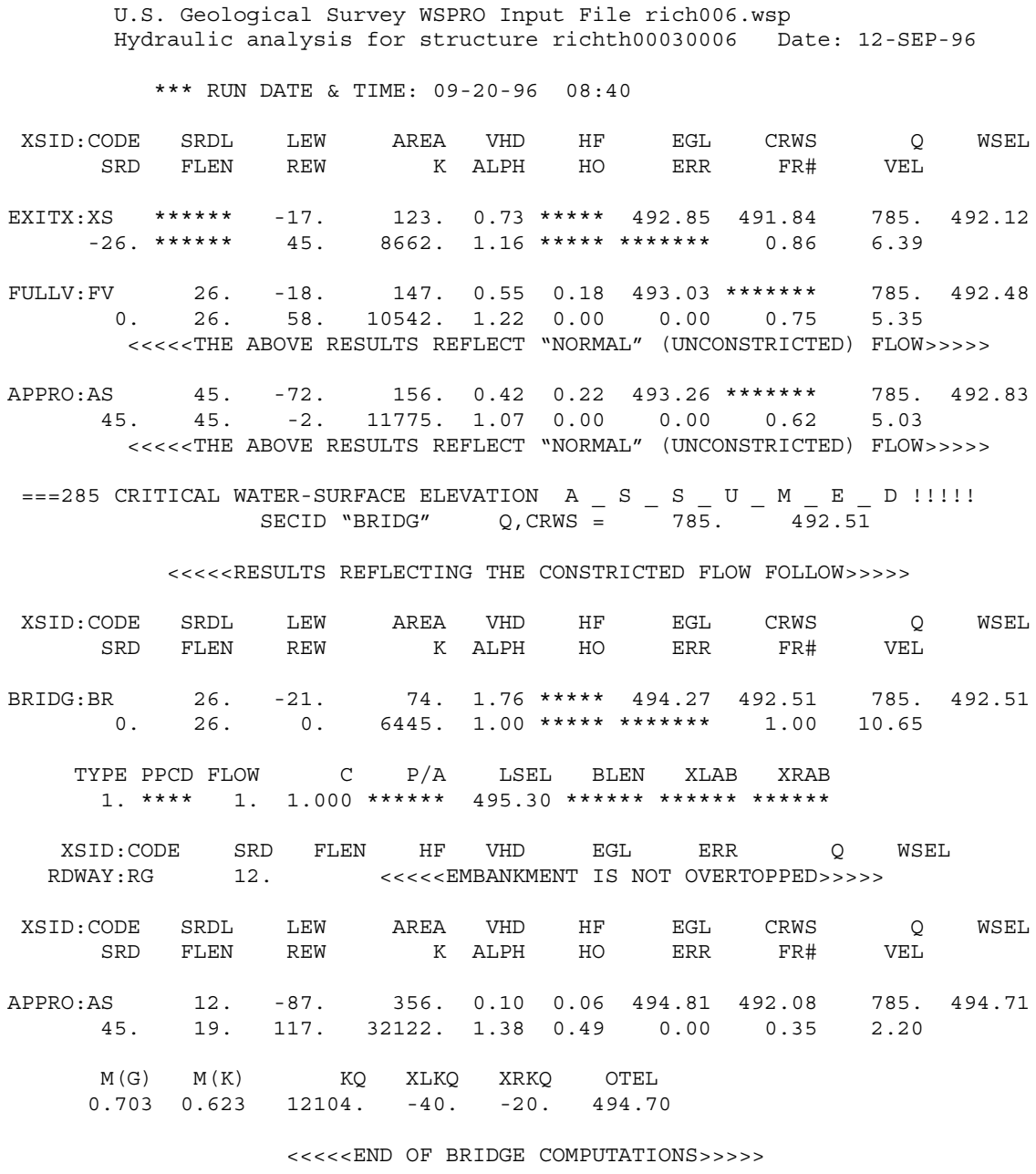

U.S. Geological Survey WSPRO Input File rich006.wsp

Hydraulic analysis for structure richth00030006 Date: 12-SEP-96

*** RUN DATE \& TIME: 09-20-96 08:40

FIRST USER DEFINED TABLE.

\begin{tabular}{|c|c|c|c|c|c|c|c|c|}
\hline XSID : CODE & SRD & LEW & REW & $\mathrm{Q}$ & $\mathrm{K}$ & AREA & VEL & WSEL \\
\hline EXITX : XS & -26 & -17 & 45. & 785. & 8662 . & 123. & 6.39 & 492.12 \\
\hline FULLV : FV & 0 & -18 & 58. & 785. & 10542 . & 147. & 5.35 & 492.48 \\
\hline BRIDG : BR & 0 & -21 & 0 & 785. & 6445 & 74 & 10.65 & 492.51 \\
\hline RDWAY : RG & \multicolumn{3}{|c|}{$12 . * * * * * * * * * * * * * *$} & \multicolumn{3}{|c|}{$0 . * * * * * * * * * * \star * * * * * * * *$} & \multicolumn{2}{|c|}{$1.00 * * * * * * * *$} \\
\hline APPRO : AS & 45 . & -87 & 117. & 785. & 32122 . & 356. & 2.20 & 494.71 \\
\hline XSID: CODE & XLKQ & $\mathrm{XRKQ}$ & & & & & & \\
\hline APPRO : AS & -40 & -20 & 1210 & & & & & \\
\hline
\end{tabular}

SECOND USER DEFINED TABLE.

\begin{tabular}{|c|c|c|c|c|c|c|c|c|c|}
\hline XSID : CODE & CRWS & FR\# & YMIN & YMAX & $\mathrm{HF}$ & HO & VHD & EGL & \\
\hline EXITX:XS & 491.84 & 0.86 & 488.20 & $502.12 * *$ & $\star \star \star \star \star \star \star * *$ & $\star * \star * *$ & 0.73 & 492.85 & 192. \\
\hline JI. & 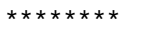 & & & 02.12 & 0.18 & & & & \\
\hline 1 & & 00 & & $495.56 * *$ & & & & & \\
\hline & 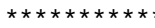 & 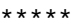 & & & & & & & \\
\hline PPRO:AS & 492.08 & 0.35 & 489.14 & 505.25 & 0.06 & 0.49 & 0.10 & 494.81 & 494 \\
\hline
\end{tabular}




\section{WSPRO OUTPUT FILE (continued)}

1 U.S. Geological Survey wSPRO Input File rich006.wsp

Hydraulic analysis for structure richth00030006 Date: 12-SEP-96

*** RUN DATE \& TIME: 09-20-96 08:40

$\begin{array}{rrrrrrrrrr}\text { XSID : CODE } & \text { SRDL } & \text { LEW } & \text { AREA } & \text { VHD } & \text { HF } & \text { EGL } & \text { CRWS } & \text { Q } & \text { WSEL } \\ \text { SRD } & \text { FLEN } & \text { REW } & \text { K } & \text { ALPH } & \text { HO } & \text { ERR } & \text { FR\# } & \text { VEL } & \\ \text { EXITX : XS } * * * * * & -18 . & 172 . & 0.86 * * * * * & 493.61 & 492.39 & 1080 . & 492.75 \\ -26 . * * * * * * & 93 . & 11919 . & 1.39 * * * * * & * * * * * * * & 1.06 & 6.29\end{array}$

$===135$ CONVEYANCE RATIO OUTSIDE OF RECOMMENDED LIMITS .

"FULLV" KRATIO $=1.44$

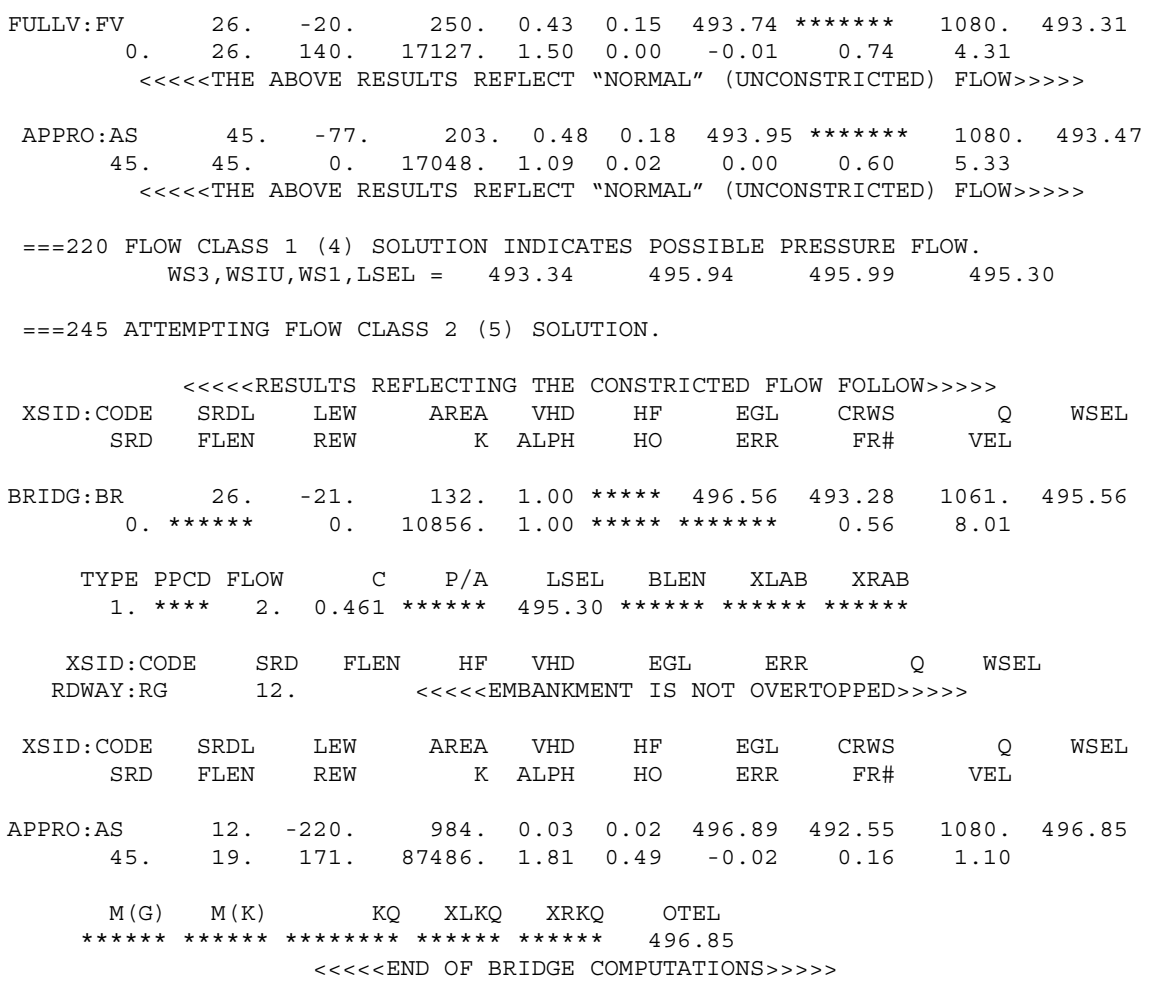

FIRST USER DEFINED TABLE.

\begin{tabular}{lrrrrrrrr} 
XSID : CODE & SRD & LEW & REW & Q & K & AREA & VEL & WSEL \\
EXITX : XS & -26. & -18. & 93. & 1080. & 11919. & 172. & 6.29 & 492.75 \\
FULLV : FV & 0. & -20. & 140. & 1080. & 17127. & 250. & 4.31 & 493.31 \\
BRIDG : BR & 0. & -21. & 0. & 1061. & 10856. & 132. & 8.01 & 495.56 \\
RDWAY : RG & \multicolumn{2}{c}{$12 . * * * * * * * * * * * * *$} & $0 . * * * * * * * * * * * * * * * *$ & $1.00 * * * * * * *$ \\
APPRO : AS & 45. & -220. & 171. & 1080. & 87486. & 984. & 1.10 & 496.85
\end{tabular}

SECOND USER DEFINED TABLE.

$\begin{array}{lrrrrrrrrr}\text { XSID : CODE } & \text { CRWS } & \text { FR\# } & \text { YMIN } & \text { YMAX } & \text { HF } & \text { HO } & \text { VHD } & \text { EGL } & \text { WSEL } \\ \text { EXITX:XS } & 492.39 & 1.06 & 488.20 & 502.12 * * * * * * * * * * & 0.86 & 493.61 & 492.75 \\ \text { FULLV:FV } & * * * * * * * * & 0.74 & 488.20 & 502.12 & 0.15 & 0.00 & 0.43 & 493.74 & 493.31 \\ \text { BRIDG:BR } & 493.28 & 0.56 & 488.10 & 495.56 * * * * * * * * * * & 1.00 & 496.56 & 495.56 \\ \text { RDWAY: RG } & * * * * * * * * * * * * * * * * & 498.61 & 504.14 * * * * * * * * * * * * & 0.00 & 500.28 * * * * * * * \\ \text { APPRO:AS } & 492.55 & 0.16 & 489.14 & 505.25 & 0.02 & 0.49 & 0.03 & 496.89 & 496.85\end{array}$




\section{APPENDIX C:}

\section{BED-MATERIAL PARTICAL-SIZE DISTRIBUTION}




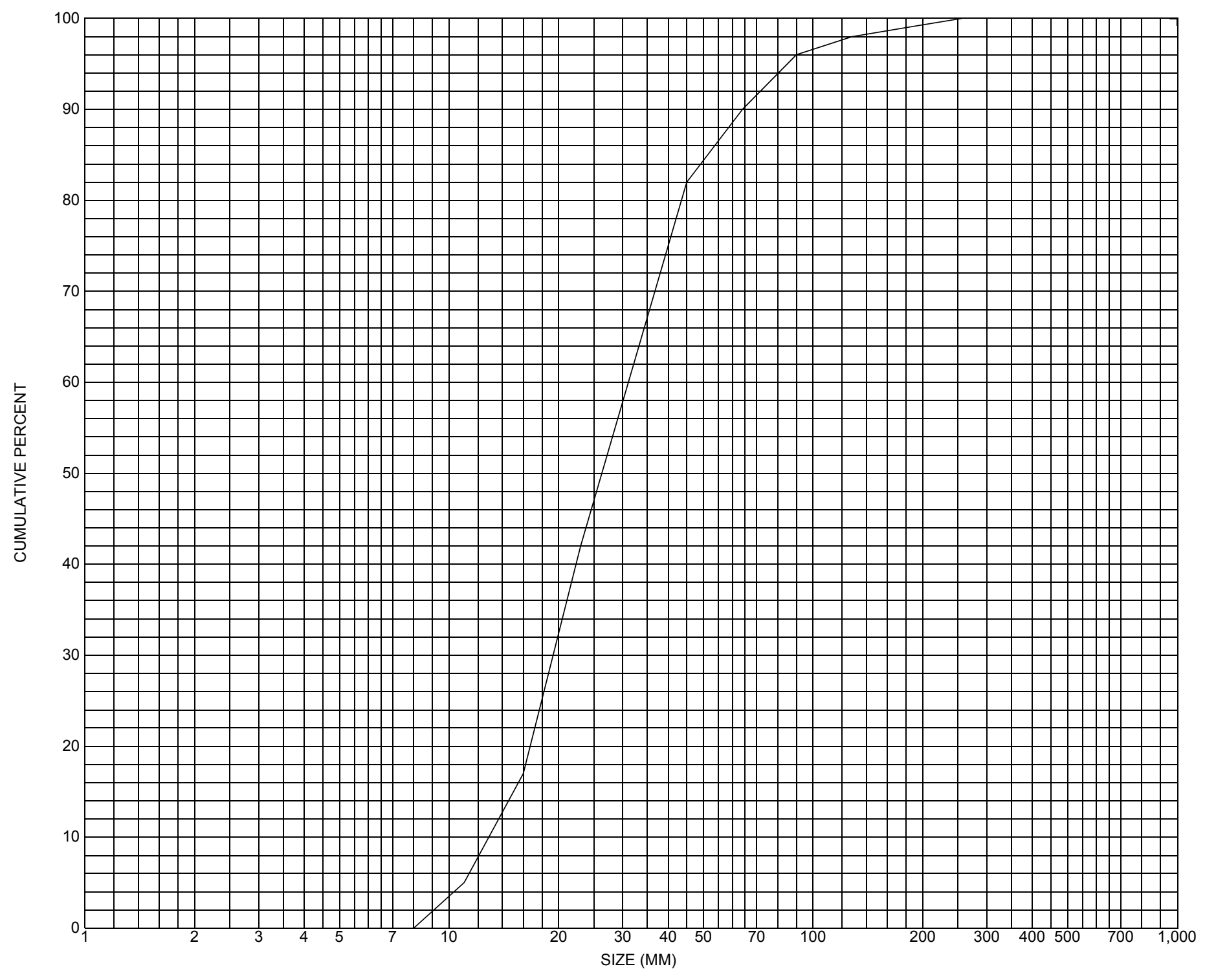

Appendix C. Bed material particle-size distribution for one pebble count transect in the channel approach of structure RICHTH00030006, in Richford, Vermont. 


\section{APPENDIX D: \\ HISTORICAL DATA FORM}




\section{Structure Number RICHTH00030006}

\section{General Location Descriptive}

Data collected by (First Initial, Full last name) E. BOEHMLER

Date $(M M / D D / Y Y) \_\mathbf{0 3} / \underline{09} / \underline{95}$

Highway District Number (I - 2; nn) $\mathbf{0 8}$

Town (FIPS place code; I - 4; nnnnn) $\mathbf{5 9 1 2 5}$

Waterway (I - 6) UNNAMED BROOK

Route Number TH003

Topographic Map Richford

Latitude (I - 16; nnnn.n) 44597
County (FIPS county code; I - 3; nnn)

Mile marker (I - 11; nnn.nnn) $\mathbf{0 0 0 6 8 0}$

Road Name (I - 7): -

Vicinity $(I-9)$ 1.2 MI W JCT. VT.105

Hydrologic Unit Code: $\mathbf{0 2 0 1 0 0 0 7}$

Longitude (i - 17; nnnnn.n) $\mathbf{7 2 4 1 0}$

\section{Select Federal Inventory Codes}

FHWA Structure Number (I - 8) 20030200060611

Maintenance responsibility $(I-21 ; n n) \quad \mathbf{0 3} \quad$ Maximum span length $(I-48 ; n n n n) \underline{\mathbf{0 0 2 4}}$

Year built (I - 27; YYYY) 1900

Structure length (I - 49; nnnnnn) $\underline{\mathbf{0 0 0 0 2 6}}$

Average daily traffic, ADT (I - 29; nnnnnn) $\underline{001025}$ Deck Width (I-52; nn.n) 234

Year of ADT (I - 30; YY) $\mathbf{9 1}$

Channel \& Protection $(I-61 ; n) \underline{6}$

Opening skew to Roadway $(I-34 ; n n) \quad \mathbf{0 0}$

Waterway adequacy $(I-71 ; n) \quad 5$

Operational status $(I-41 ; X)$ A

Underwater Inspection Frequency $(I-92 B ; X Y Y) \_\mathbf{N}$

Structure type (I - 43; nnn) 104

Year Reconstructed $(I$ - 106) $\mathbf{0 0 0 0}$

Approach span structure type (I - 44; nnn) $\mathbf{0 0 0}$ Clear span (nnn.n ft) _

Number of spans (I - 45; nnn) $\mathbf{0 0 1}$

Vertical clearance from streambed (nnn.n ft) $\underline{\mathbf{5 . 0}}$

Number of approach spans (I - 46; nnnn) $\mathbf{0 0 0 0}$

Waterway of full opening $\left(n n n . n \mathrm{ft}^{2}\right)$

Comments:

The structural inspection report of 5/12/94 indicates the structure is a single span concrete T-beam type bridge. The left abutment wall has a full height vertical crack visible and areas of moderate to heavy concrete scaling. The upstream and downstream left wingwalls also show heavy to moderate concrete scaling. The footing of the left abutment is partially exposed and heavily scaled with some scour noted at the upstream end but no undermining. The right abutment wall has some light scaling noted and the upstream and downstream right wingwalls have moderate to heavy concrete scaling. The exposed footing appears to have a newer concrete facing and is in good condition. Apparently, (Continued, page 31) 


\section{Bridge Hydrologic Data}

Is there hydrologic data available? $\underline{\mathbf{N}}$ if No, type ctrl-n $h \quad$ VTAOT Drainage area $\left(m i^{2}\right)$ : -

Terrain character:

Stream character \& type: -

Streambed material:

Discharge Data (cfs):

$$
\begin{aligned}
& Q_{2.33}- \\
& Q_{50}-
\end{aligned}
$$

Record flood date (MM / DD /YY):

Estimated Discharge (cfs): Ice conditions (Heavy, Moderate, Light) : -

$$
\mathrm{Q}_{10} \ldots
$$$$
Q_{25} \ldots
$$

Water surface elevation $(f t):-$ $(\mathrm{ft} / \mathrm{s})$ :

Velocity at $Q$ Debris (Heavy, Moderate, Light):

The stage increases to maximum highwater elevation (Rapidly, Not rapidly):

The stream response is (Flashy, Not flashy):

Describe any significant site conditions upstream or downstream that may influence the stream's stage: -

Watershed storage area (in percent):

The watershed storage area is: - (1-mainly at the headwaters; 2- uniformly distributed; 3-immediatly upstream oi the site)

Water Surface Elevation Estimates for Existing Structure:

\begin{tabular}{|l|l|l|l|l|l|}
\hline Peak discharge frequency & $Q_{2.33}$ & $Q_{10}$ & $Q_{25}$ & $Q_{50}$ & $Q_{100}$ \\
Water surface elevation (ft)) & - & - & - & - & - \\
Velocity $(\mathrm{ft} / \mathrm{sec})$ & - & - & - & - & - \\
\hline
\end{tabular}

Long term stream bed changes: -

Is the roadway overtopped below the $\mathrm{Q}_{100}$ ? (Yes, No, Unknown): $\mathbf{U}$ Frequency: Relief Elevation (ft): Discharge over roadway at $Q_{100}\left(f^{3} / \mathrm{sec}\right)$ :

Are there other structures nearby? (Yes, No, Unknown): $\underline{\mathbf{U}}$ Upstream distance (miles): Town: If No or Unknown, type ctrl-n os Highway No. :Structure No. : Year Built:

Clear span (ft): Clear Height $(f t)$ : Full Waterway $\left(f^{2}\right)$ : 
Downstream distance (miles): Town: Year Built:

Highway No. : Structure No. : Structure Type:

Clear span (ft): Clear Height (ft): Full Waterway $\left(f^{2}\right)$ :

Comments:

there was an undermining problem at one time, and the facing on the footing was constructed as a result, the report indicated. The channel makes a sharp turn into the structure, with flow attacking the right abutment. Point bars located along the left abutment are noted and visible in photographs. There is some riprap protection noted along the right abutment.

\section{USGS Watershed Data}

Watershed Hydrographic Data

Drainage area $(D A)$ $\mathrm{mi}^{2}$ Lake and pond area 0.03 $\mathrm{mi}^{2}$

Watershed storage (ST) 0.7

Bridge site elevation 433 $\mathrm{ft}$ $\%$

Main channel length 4.26 $\mathrm{mi}$ $10 \%$ channel length elevation 440 $\mathrm{ft} \quad 85 \%$ channel length elevation 935 $\mathrm{ft}$

Main channel slope $(S)$ (S) 154.93 $\mathrm{ft} / \mathrm{mi}$

Watershed Precipitation Data

Average site precipitation in Average headwater precipitation in

Maximum 2yr-24hr precipitation event $(124,2)$ in

Average seasonal snowfall (Sn) $\mathrm{ft}$ 


\section{Bridge Plan Data}

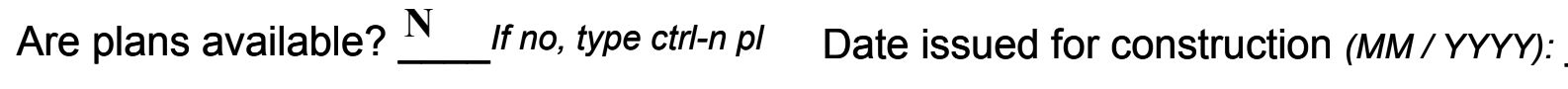

Project Number

Minimum channel bed elevation:

Low superstructure elevation: USLAB DSLAB USRAB DSRAB Benchmark location description:

NO BENCHMARK INFORMATION

Reference Point (MSL, Arbitrary, Other): Datum (NAD27, NAD83, Other):

Foundation Type: 4

If 1: Footing Thickness

If 2: Pile Type:

If 3: Footing bottom elevation:

Is boring information available? $\mathrm{N}$

Foundation Material Type: $\mathbf{3}$

(1-Spreadfooting; 2-Pile; 3- Gravity; 4-Unknown)

Footing bottom elevation: -

Briefly describe material at foundation bottom elevation or around piles:

NO FOUNDATION MATERIAL INFORMATION

Comments:

NO PLANS. 


\section{Cross-sectional Data}

Is cross-sectional data available? $\underline{\mathbf{N}}$ If no, type ctrl-n xs

Source (FEMA, VTAOT, Other)? -

Comments: NO CROSS SECTION INFORMATION

\begin{tabular}{|l|l|l|l|l|l|l|l|l|l|l|l|}
\hline Station & - & - & - & - & - & - & - & - & - & - & - \\
\hline Feature & - & - & - & - & - & - & - & - & - & - & - \\
\hline $\begin{array}{l}\text { Low cord } \\
\text { elevation }\end{array}$ & - & - & - & - & - & - & - & - & - & - & - \\
\hline $\begin{array}{l}\text { Bed } \\
\text { elevation }\end{array}$ & - & - & - & - & - & - & - & - & - & - & - \\
\hline $\begin{array}{l}\text { Low cord to } \\
\text { bed length }\end{array}$ & - & - & - & - & - & - & - & - & - & - & - \\
\hline Station & - & - & - & - & - & - & - & - & - & - & - \\
\hline Feature & - & - & - & - & - & - & - & - & - & - & - \\
\hline $\begin{array}{l}\text { Low cord } \\
\text { elevation }\end{array}$ & - & - & - & - & - & - & - & - & - & - & - \\
\hline $\begin{array}{l}\text { Bed } \\
\text { elevation }\end{array}$ & - & - & - & - & - & - & - & - & - & - & - \\
\hline $\begin{array}{l}\text { Low cord to } \\
\text { bed length }\end{array}$ & - & - & - & - & - & - & - & - & - & - & - \\
\hline
\end{tabular}

Source (FEMA, VTAOT, Other)?

Comments: NO CROSS SECTION INFORMATION

\begin{tabular}{|l|l|l|l|l|l|l|l|l|l|l|l|}
\hline Station & - & - & - & - & - & - & - & - & - & - & - \\
\hline Feature & - & - & - & - & - & - & - & - & - & - & - \\
\hline $\begin{array}{l}\text { Low cord } \\
\text { elevation }\end{array}$ & - & - & - & - & - & - & - & - & - & - & - \\
\hline $\begin{array}{l}\text { Bed } \\
\text { elevation }\end{array}$ & - & - & - & - & - & - & - & - & - & - & - \\
\hline $\begin{array}{l}\text { Low cord to } \\
\text { bed length }\end{array}$ & - & - & - & - & - & - & - & - & - & - & - \\
\hline Station & - & - & - & - & - & - & - & - & - & - & - \\
\hline Feature & - & - & - & - & - & - & - & - & - & - & - \\
\hline $\begin{array}{l}\text { Low cord } \\
\text { elevation }\end{array}$ & - & - & - & - & - & - & - & - & - & - & - \\
\hline $\begin{array}{l}\text { Bed } \\
\text { elevation }\end{array}$ & - & - & - & - & - & - & - & - & - & - & - \\
\hline $\begin{array}{l}\text { Low cord to } \\
\text { bed length }\end{array}$ & - & - & - & - & - & - & - & - & - & - & - \\
\hline
\end{tabular}




\section{APPENDIX E: \\ LEVEL I DATA FORM}


U. S. Geological Survey

Bridge Field Data Collection and Processing Form

Qa/Qc Check by: RB Date: $\mathbf{3 / 6 / 9 6}$

\section{Structure Number}

RICHTH00030006

Computerized by: $\underline{\mathbf{R B}}$ Date: $\mathbf{3 / 6 / 9 6}$

Reviewd by: $\quad$ RF Date: $\underline{10 / 7 / 96}$

\section{A. General Location Descriptive}

1. Data collected by (First Initial, Full last name) $\mathbf{D}$. SONG

2. Highway District Number $\mathbf{8}$

County 011

Waterway $(l-6)$ UNNAMED BROOK

Route Number $\mathbf{T H 0 0 3}$

Mile marker 000680

Date $(M M / D D / Y Y)$

$28 / 1995$

Descriptive comments:

1.2 miles to the junction with VT 105. Farmland.

Town (59125) RICHFORD

Road Name -

Hydrologic Unit Code: $\mathbf{0 2 0 1 0 0 0 7}$

\section{B. Bridge Deck Observations}
4. Surface cover... LBUS 4
RBUS 4
LBDS 4
RBDS 4
Overall 4

(2b us,ds,lb,rb: 1- Urban; 2- Suburban; 3- Row crops; 4- Pasture; 5- Shrub- and brushland; 6- Forest; 7- Wetland)
5. Ambient water surface... US 2
UB 1
DS 1
(1- pool; 2- riffle)

6. Bridge structure type 1 (1- single span; 2- multiple span; 3- single arch; 4- multiple arch; 5-cylindrical culvert; 6- box culvert; or 7- other)
7. Bridge length $\underline{26}$
(feet)
Span length $\underline{24}$
(feet)
Bridge width 23.4 (feet)

\section{Road approach to bridge:}
8. LB 0
RB 0
( 0 even, 1- lower, 2- higher)
9. LB_
RB 1
(1- Paved, 2- Not paved)

10. Embankment slope (run / rise in feet / foot)

US left

1.1:1

US right $\quad 2.3: 1$

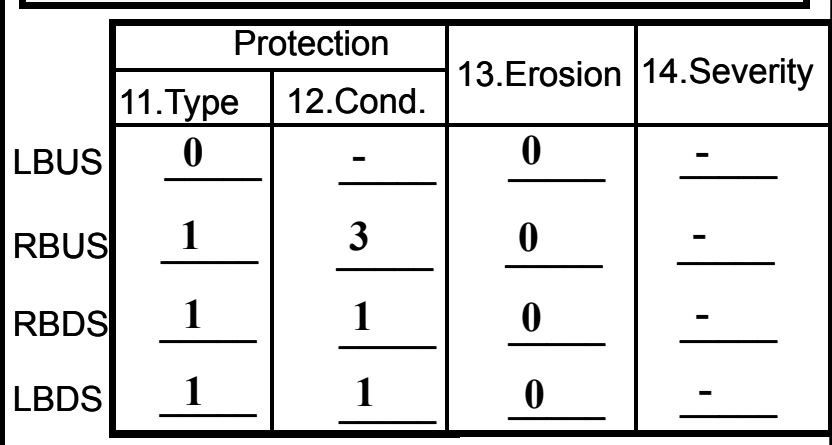

Bank protection types: 0- none; 1- $<12$ inches;

2- < 36 inches; 3- < 48 inches;

4- < 60 inches; 5- wall / artificial levee

Bank protection conditions: 1- good; 2- slumped;

3- eroded; 4- failed

Erosion: 0 - none; 1- channel erosion; 2 -

road wash; 3- both; 4- other

Erosion Severity: 0 - none; 1- slight; 2- moderate; 3- severe

\section{Channel approach to bridge (BF):}

15. Angle of approach: $\mathbf{2 0}$

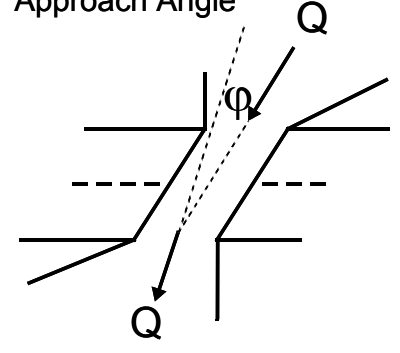

17. Channel impact zone 1:

Where? RB (LB, RB)

Range? 5 feet US

Channel impact zone 2:

Where? LB $(L B, R B)$

Range? $\underline{40}$ feet $\underline{\mathrm{DS}}$ (US, UB, DS) to $\underline{\mathbf{8 0}}$ feet $\underline{\mathrm{DS}}$

Impact Severity: 0- none to very slight; 1- Slight; 2- Moderate; 3- Severe
16. Bridge skew: 40

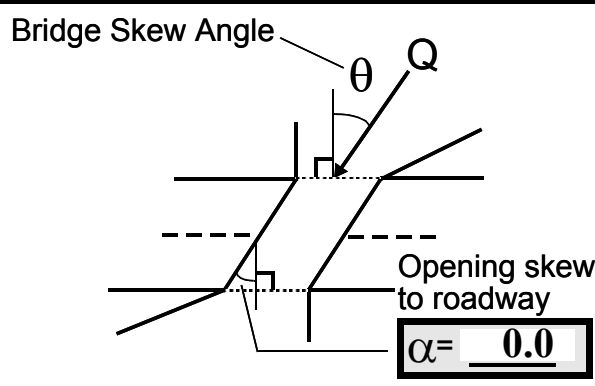

Exist? $\mathbf{Y}(Y$ or $N)$

Severity 2

, UB, DS) to 10 feet DS

Exist? $\mathbf{Y}(Y$ or $N)$

Severity 2 
18. Bridge Type: 1a

1a- Vertical abutments with wingwalls

1 b- Vertical abutments without wingwalls

2- Vertical abutments and wingwalls, sloping embankment

Wingwalls perpendicular to abut. face

3- Spill through abutments

4- Sloping embankment, vertical wingwalls and abutments

1a with wingwalls

Wingwall angle less than $90^{\circ}$.

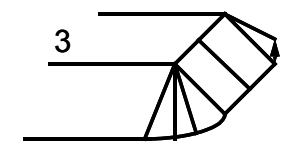

陪

19. Bridge Deck Comments (surface cover variations, measured bridge and span lengths, bridge type variations, approach overflow width, etc.)

7. Values are from VT AOT files.

18. Bridge is a combination of $1 \mathrm{a}$ and 4 , but sloping wingwalls end at the low chord.

\section{Upstream Channel Assessment}

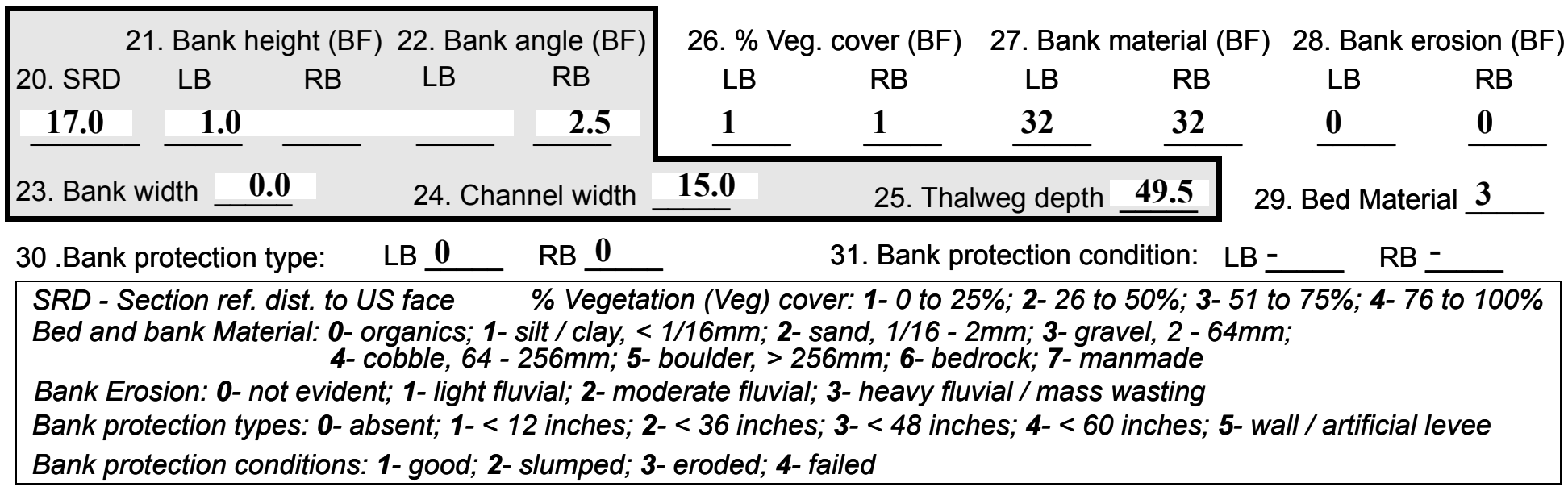

32. Comments (bank material variation, minor inflows, protection extent, etc.):

The left bank US is a path for cows that continues under the bridge. There is some erosion because of lack of vegetation. 
33.Point/Side bar present? $\mathbf{N}(Y \text { or } N \text {. if } N \text { type ctrl-n } p b)_{34}$. Mid-bar distance:

35. Mid-bar width: -

36. Point bar extent: feet (US, UB) to feet (US, UB, DS) positioned $\%$ LB to $\% \mathrm{RB}$

37. Material:

38. Point or side bar comments (Circle Point or Side; Note additional bars, material variation, status, etc.):

NO POINT BARS

39. Is a cut-bank present? $\underline{\mathbf{N}}$ (Y or if $\mathrm{N}$ type $c t r l-n c b)$

40. Where? (LB or RB)

41. Mid-bank distance: -

42. Cut bank extent: feet (US, UB) to feet (US, UB, DS)

43. Bank damage: (1- eroded and/or creep; 2- slip failure; 3- block failure)

44. Cut bank comments (eg. additional cut banks, protection condition, etc.):

NO CUT BANKS

45. Is channel scour present? $\mathbf{N}$ (Yor if $N$ type ctrl-n cs)

47. Scour dimensions: Length Width Depth : 46. Mid-scour distance: -

48. Scour comments (eg. additional scour areas, local scouring process, etc.):

NO CHANNEL SCOUR
49. Are there major confluences? $\mathbf{N}$

51. Confluence 1: Distance Confluence 2: Distance -
52. Enters on -

Enters on -
(Y or if $N$ type ctrl-n mc) ( $(L B$ or $R B)$ (LB or $R B)$
54. Confluence comments (eg. confluence name):

NO MAJOR CONFLUENCES

\section{Under Bridge Channel Assessment}

55. Channel restraint (BF)? LB 2

\begin{tabular}{|ccccc}
\hline \multicolumn{2}{|c}{56. Height (BF) } & \multicolumn{3}{c}{57 Angle (BF) } \\
LB & RB & LB & RB \\
9.5 & & & $\mathbf{0 . 5}$ & \\
\hline
\end{tabular}
(1- natural bank; 2- abutment; 3- artificial levee)
53. Type(1- perennial; 2- ephemeral) Type (1-perennial; 2- ephemeral)
58. Bank width (BF) 59. Channel width $(\mathrm{Amb})$ 61. Material (BF) LB RB $\underline{2} \quad \underline{7}$ 60. Thalweg depth (Amb) $\mathbf{9 0 . 0}$ 63. Bed Material -

Bed and bank Material: 0- organics; 1- silt / clay, < 1/16mm; 2- sand, 1/16 - 2mm; 3- gravel, 2 - 64mm; 4- cobble, 64 - 256mm; 5- boulder, > 256mm; 6- bedrock; 7- manmade

Bank Erosion: 0- not evident; 1- light fluvial; 2- moderate fluvial; 3- heavy fluvial / mass wasting

64. Comments (bank material variation, minor inflows, protection extent, etc.): 3

Ambient channel runs along the impact zone at the right abutment. 
65. Debris and Ice Is there debris accumulation?

(Yor $N)$ 66. Where? $\mathbf{N}$

(1- Upstream; 2- At bridge; 3- Both)

67. Debris Potential ( 1- Low; 2- Moderate; 3- High)

68. Capture Efficiency 1 (1-Low; 2- Moderate; 3- High)

69. Is there evidence of ice build-up? 1 ( $Y$ or $N)$ Ice Blockage Potential $\mathbf{N}$ (1-Low; 2- Moderate; 3- High)

70. Debris and Ice Comments:

1

No debris accumulation, slight bridge constriction of channel.

\begin{tabular}{|l|c|c|c|c|c|c|c|c|}
\hline Abutments & $\begin{array}{c}\text { 71. Attack } \\
\angle \text { (BF) }\end{array}$ & $\begin{array}{c}72 \text {. Slope } \angle \\
\text { (Qmax) }\end{array}$ & $\begin{array}{c}\text { 73. Toe } \\
\text { loc. (BF) }\end{array}$ & $\begin{array}{c}\text { 74. Scour } \\
\text { Condition }\end{array}$ & $\begin{array}{c}75 . \text { Scour } \\
\text { depth }\end{array}$ & $\begin{array}{c}\text { 76. Exposure } \\
\text { depth }\end{array}$ & 77. Material & 78. Length \\
\hline LABUT & & $\mathbf{0}$ & $\mathbf{9 0}$ & $\mathbf{2}$ & $\mathbf{2}$ & $\mathbf{0}$ & $\mathbf{0 . 5}$ & $\mathbf{9 0 . 0}$ \\
\hline RABUT & $\mathbf{1}$ & $\mathbf{4 0}$ & $\mathbf{9 0}$ & & & $\mathbf{2}$ & $\mathbf{2}$ & $\mathbf{2 1 . 0}$ \\
\hline
\end{tabular}

Pushed: $L B$ or RB

Toe Location (Loc.): 0- even, 1- set back, 2- protrudes

Scour cond.: 0- not evident; 1- evident (comment); 2- footing exposed; 3-undermined footing; 4- piling exposed; 5- settled; 6- failed

Materials: 1- Concrete; 2- Stone masonry or drywall; 3- steel or metal; 4- wood

79. Abutment comments (eg. undermined penetration, unusual scour processes, debris, etc.):

0.5

2

1

Historical records note a previous undermining problem of the right abutment which was remedied by a new footing.

80. Wingwalls:

Exist? Material? Scour Scour Exposure $\begin{aligned} & 81 . \\ & \text { Angle? Length? }\end{aligned}$ Condition? depth? depth?

USLWW:

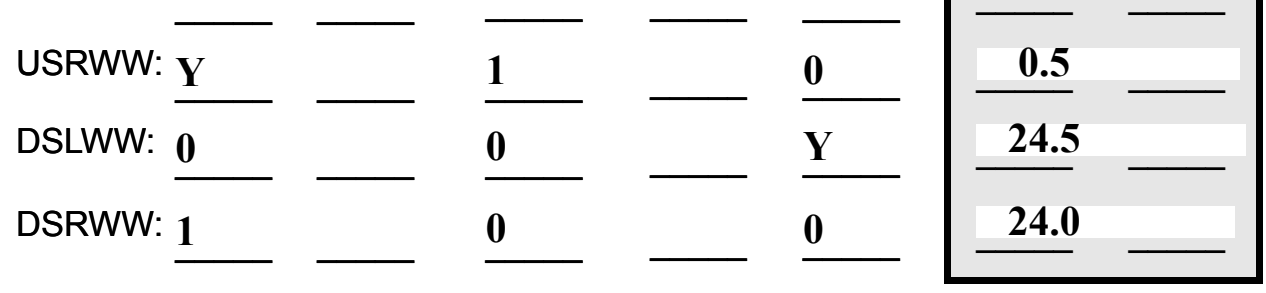

Wingwall materials: 1- Concrete; 2- Stone masonry or drywall; 3- steel or metal; 4- wood

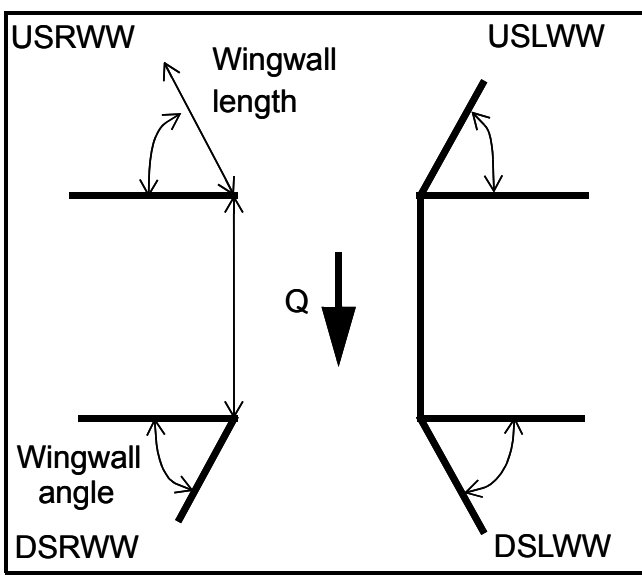

82. Bank / Bridge Protection:

\begin{tabular}{|l|l|l|l|l|l|l|c|c|}
\hline Location & USLWW & USRWW & LABUT & RABUT & LB & RB & DSLWW & DSRWW \\
\hline Type & $\mathbf{0}$ & $\mathbf{0}$ & $\mathbf{Y}$ & $\mathbf{0 . 5}$ & - & $\mathbf{1}$ & - & $\mathbf{1}$ \\
\hline Condition & $\mathbf{Y}$ & $\mathbf{0}$ & $\mathbf{1}$ & $\mathbf{2}$ & - & $\mathbf{1}$ & - & $\mathbf{2}$ \\
\hline Extent & $\mathbf{1}$ & $\mathbf{0}$ & $\mathbf{2}$ & $\mathbf{0}$ & $\mathbf{2}$ & $\mathbf{0}$ & $\mathbf{2}$ & $\mathbf{0}$ \\
\hline
\end{tabular}

Bank / Bridge protection types: 0- absent; 1- < 12 inches; 2- < 36 inches; 3- < 48 inches; 4- < 60 inches; 
83. Wingwall and protection comments (eg. undermined penetration, unusual scour processes, etc.):

-
-
-
-
0
-
-
0
-
-

\section{Piers:}

84. Are there piers? _ _ (Y or if N type ctrl-n pr)

\begin{tabular}{|l|c|l|l|l|l|l|l|}
\hline \multirow{2}{*}{$\begin{array}{l}85 . \\
\text { Pier no. }\end{array}$} & \multicolumn{3}{|c|}{ width (w) feet } & \multicolumn{3}{c|}{ elevation (e) feet } \\
\cline { 2 - 8 } & w1 & w2 & w3 & e@w1 & e@w2 & e@w3 \\
\hline Pier 1 & & & & $\mathbf{3 0 . 0}$ & $\mathbf{1 5 . 0}$ & $\mathbf{9 0 . 0}$ \\
\hline Pier 2 & & & $\mathbf{7 . 5}$ & $\mathbf{1 0 . 5}$ & $\mathbf{6 0 . 0}$ & $\mathbf{5 5 . 0}$ \\
\hline Pier 3 & $\mathbf{7 . 5}$ & - & - & - & - & - \\
\hline Pier 4 & - & - & - & - & - & - \\
\hline
\end{tabular}

\begin{tabular}{|l|l|l|l|l|}
\hline Level 1 Pier Descr. & 1 & \multicolumn{1}{|c|}{2} & 3 & \multicolumn{1}{|c|}{} \\
\hline 86. Location (BF) & & - & - & - \\
\hline 87. Type & & - & - & - \\
\hline 88. Material & & - & - & - \\
\hline 89. Shape & & - & - & - \\
\hline 90. Inclined? & & - & - & - \\
\hline 91. Attack $\angle$ (BF) & & - & - & - \\
\hline 92. Pushed & & - & - & - \\
\hline 93. Length (feet) & - & - & - & - \\
\hline 94. \# of piles & & - & - & - \\
\hline 95. Cross-members & & - & - & - \\
\hline 96. Scour Condition & & - & - & - \\
\hline 97. Scour depth & $\mathbf{N}$ & - & - & - \\
\hline 98. Exposure depth & - & - & - & - \\
\hline
\end{tabular}

LFP, LTB, LB, MCL, MCM, MCR, RB, RTB, RFP

1- Solid pier, 2- column, 3- bent

1-Wood; 2- concrete; 3- metal; 4- stone

1- Round; 2- Square; 3- Pointed

Y-yes; $N$ - no

$L B$ or $R B$

0- none; 1- laterals; 2- diagonals; 3- both

0- not evident; 1- evident (comment);

2- footing exposed; 3- piling exposed;

4- undermined footing; 5- settled; 6- failed 
99. Pier comments (eg. undermined penetration, protection and protection extent, unusual scour processes, etc.):

-
-
-
-
-
-
-
-
-

100.

\section{E. Downstream Channel Assessment}

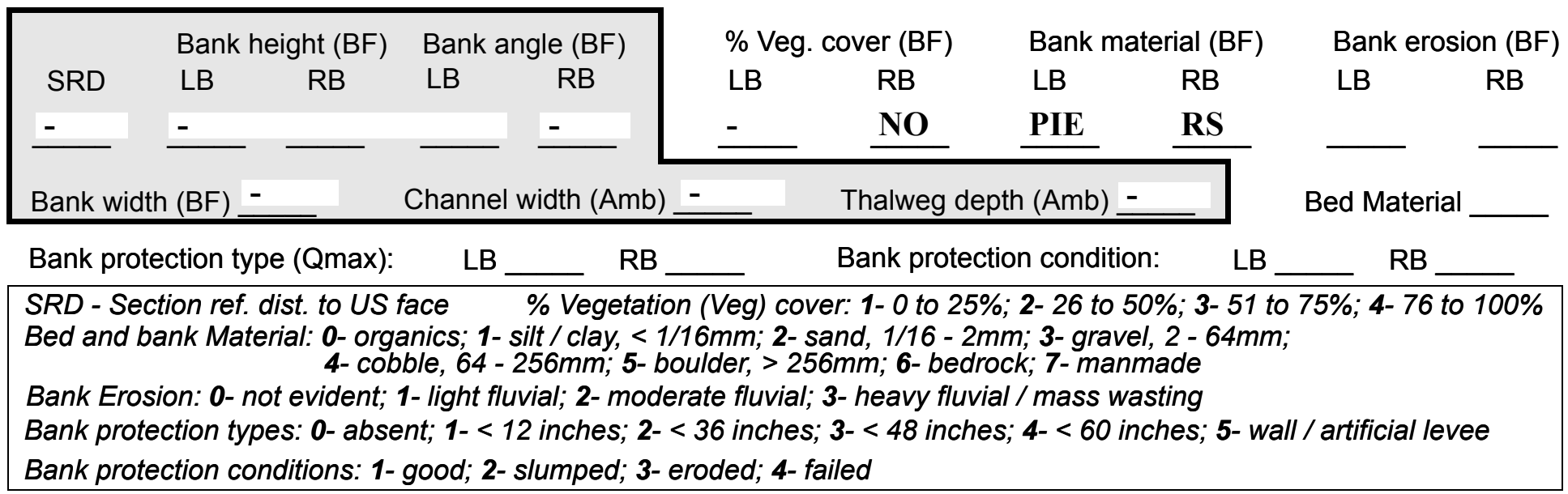

Comments (eg. bank material variation, minor inflows, protection extent, etc.):

Bed material ranges from sand to gravel. The cow path continues from US and crosses the stream DS at the bridge onto the right bank. There is a little vegetation and some erosion on the right bank immediately DS of 101. Is a drop structure present? th ( $Y$ or $N$, if $N$ type ctrl-n ds) 102. Distance: __ feet 103. Drop: - feet 104. Structure material: e (1- steel sheet pile; 2- wood pile; 3- concrete; 4- other) 105. Drop structure comments (eg. downstream scour depth): bridge. 
106. Point/Side bar present? (Y or $N$. if $N$ type ctrl-n pb)Mid-bar distance:

Mid-bar width:

Point bar extent: feet

(US, UB, DS) to feet (US, UB, DS) positioned $\underline{\mathbf{N}}$ $\%$ LB to $\%$ RB

Material: NO

Point or side bar comments (Circle Point or Side; note additional bars, material variation, status, etc.):

\section{DROP STRUCTURE}

Is a cut-bank present? (Y or if $N$ type ctrl- $n$ cb) Where? (LB or $R B)$

Mid-bank distance: $\underline{\mathbf{Y}}$

Cut bank extent: $\underline{0}$ feet 10 (US, UB, DS) to 0 feet US (US, UB, DS)

Bank damage: 10 (1- eroded and/or creep; 2- slip failure; 3- block failure)

Cut bank comments (eg. additional cut banks, protection condition, etc.):

DS

o

$\mathbf{5 0}$

2,3

Is channel scour present? San (Yor if $N$ type ctrl-n cs) Mid-scour distance: $\underline{\mathbf{d}}$ to Scour dimensions: Length grav Width el_Depth: bar Positioned alo \%

Scour comments (eg. additional scour areas, local scouring process, etc.):

the left abutment.

Are there major confluences? $\mathbf{N}$ (Y or if $N$ type ctrl-n $m c)$

Confluence 1: Distance -

Confluence 2: Distance Enters on (LB or $R B)$

Enters on (LB or $R B)$
How many? -

Type (1- perennial; 2- ephemeral)

Type (1- perennial; 2- ephemeral)

Confluence comments (eg. confluence name):

NO CUT BANKS

\section{F. Geomorphic Channel Assessment}

107. Stage of reach evolution

1- Constructed

2- Stable

3- Aggraded

4- Degraded

5- Laterally unstable

6- Vertically and laterally unstable 



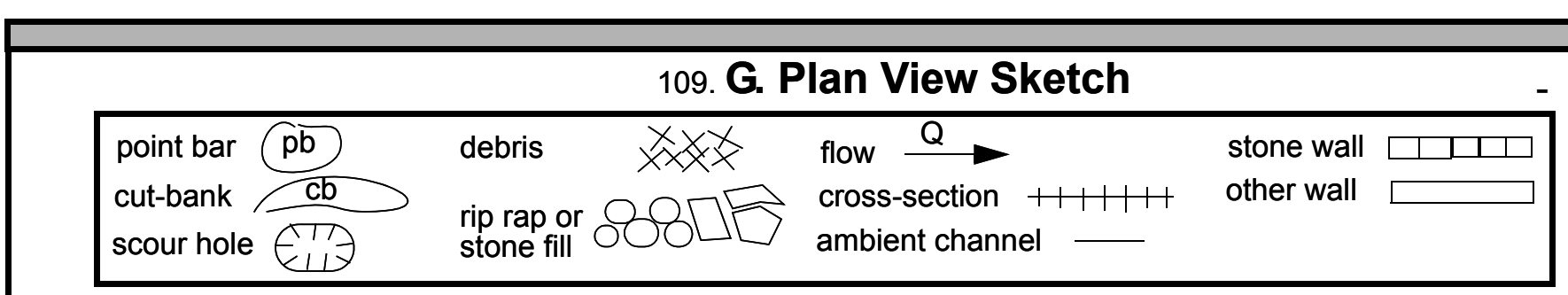


APPENDIX F:

SCOUR COMPUTATIONS 
SCOUR COMPUTATIONS

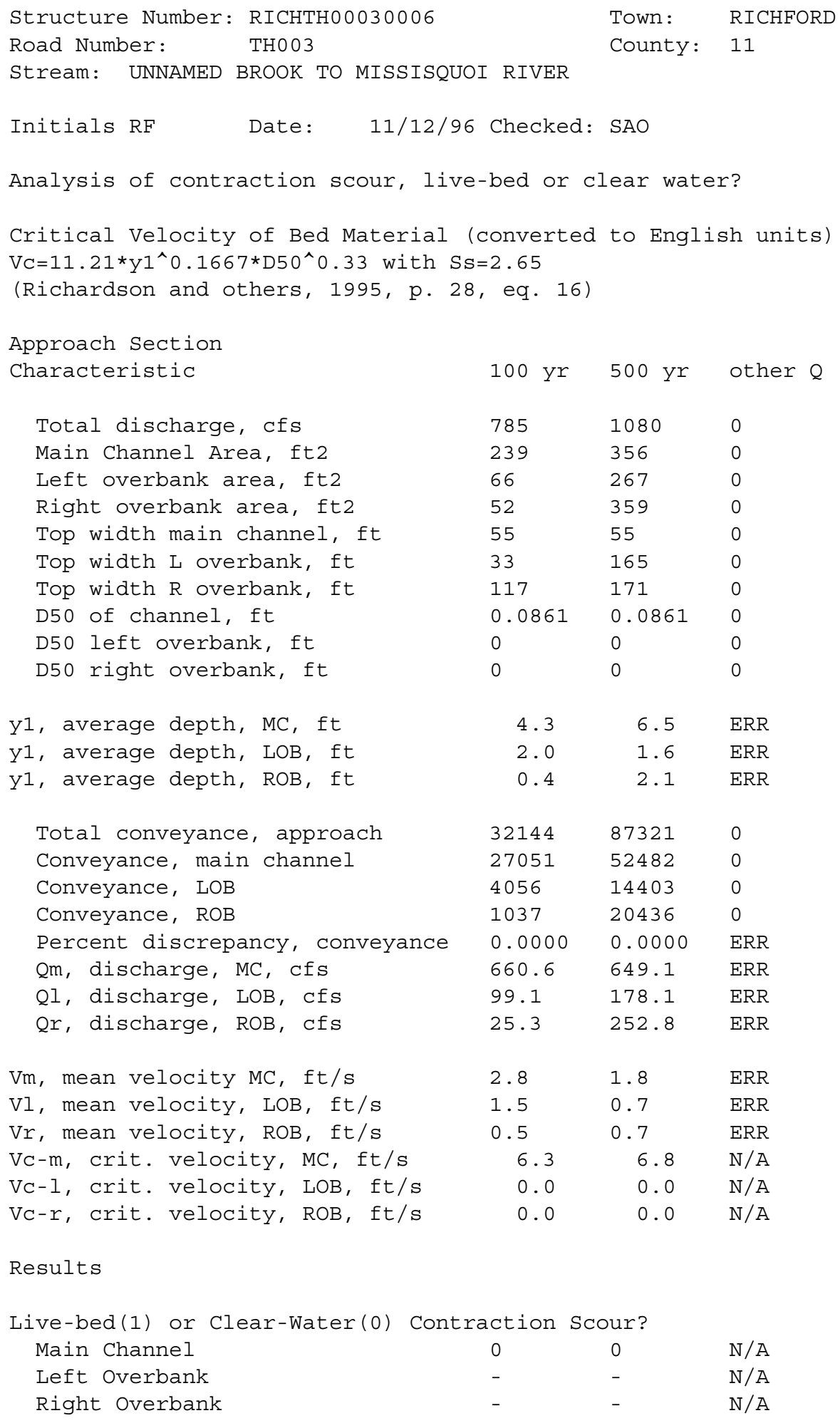




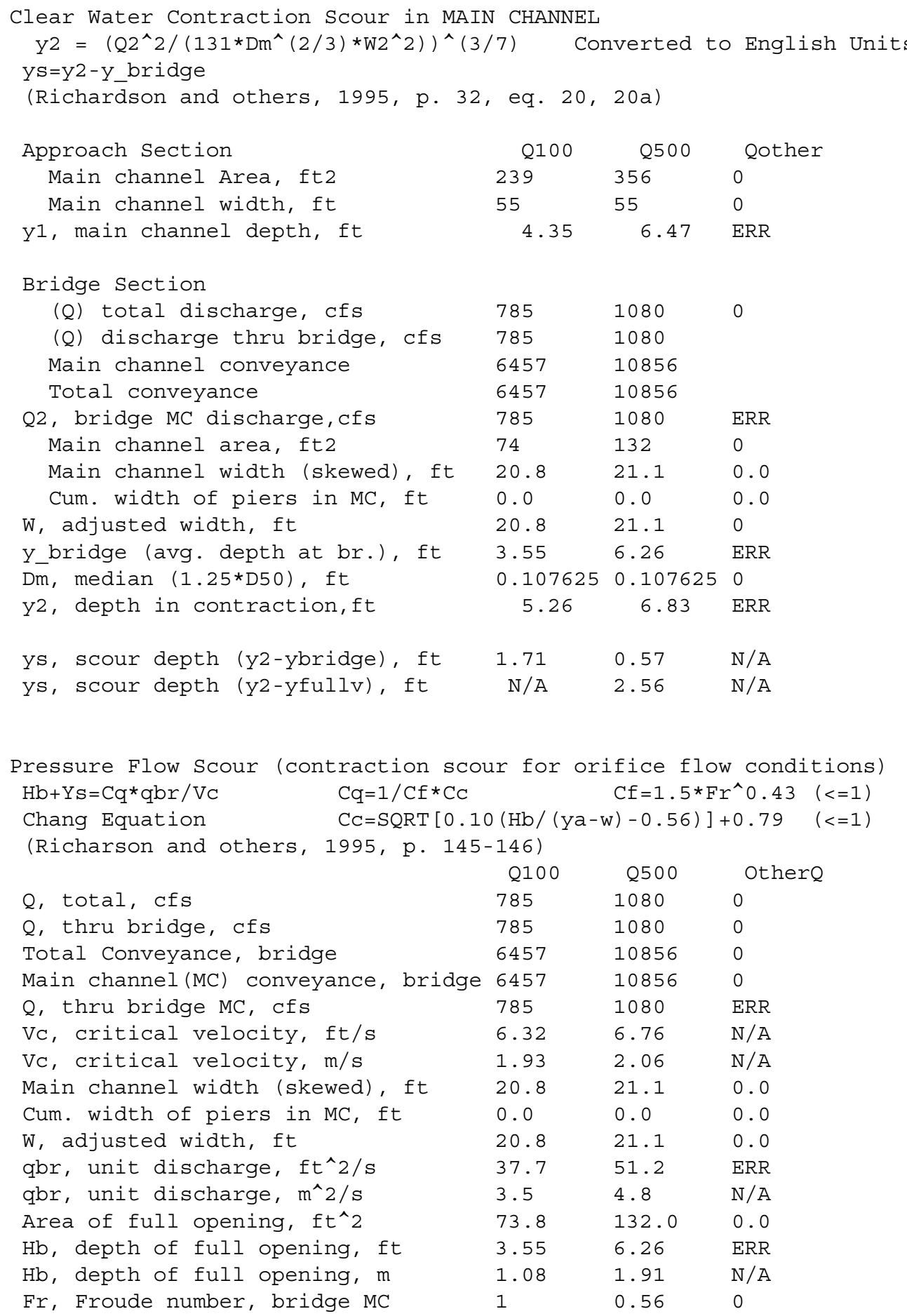




\begin{tabular}{|c|c|c|c|}
\hline Cf, Fr correction factor $(<=1.0)$ & 1.00 & 1.00 & 0.00 \\
\hline Elevation of Low Steel, ft & 0 & 495.3 & 0 \\
\hline Elevation of Bed, ft & -3.55 & 489.04 & $\mathrm{~N} / \mathrm{A}$ \\
\hline Elevation of Approach, ft & 0 & 496.85 & 0 \\
\hline Friction loss, approach, ft & 0 & 0.02 & 0 \\
\hline Elevation of WS immediately US, ft & 0.00 & 496.83 & 0.00 \\
\hline ya, depth immediately US, ft & 3.55 & 7.79 & $\mathrm{~N} / \mathrm{A}$ \\
\hline ya, depth immediately US, m & 1.08 & 2.37 & $\mathrm{~N} / \mathrm{A}$ \\
\hline Mean elevation of deck, ft & 0 & 499.1695 & 0 \\
\hline w, depth of overflow, ft $(>=0)$ & 0.00 & 0.00 & 0.00 \\
\hline Cc, vert contrac correction $(<=1.0)$ & 1.00 & 0.95 & ERR \\
\hline Ys, depth of scour, ft & $\mathrm{N} / \mathrm{A}$ & 1.75 & $\mathrm{~N} / \mathrm{A}$ \\
\hline \multicolumn{4}{|l|}{ ARMORING } \\
\hline D90 & 0.21 & 0.21 & 0 \\
\hline D95 & 0.279 & 0.279 & 0 \\
\hline Critical grain size,Dc, ft & 0.4019 & 0.1943 & ERR \\
\hline Decimal-percent coarser than Dc & 0.0225 & 0.1176 & \\
\hline Depth to armoring, ft & 52.38 & 4.37 & ERR \\
\hline
\end{tabular}

Abutment scour

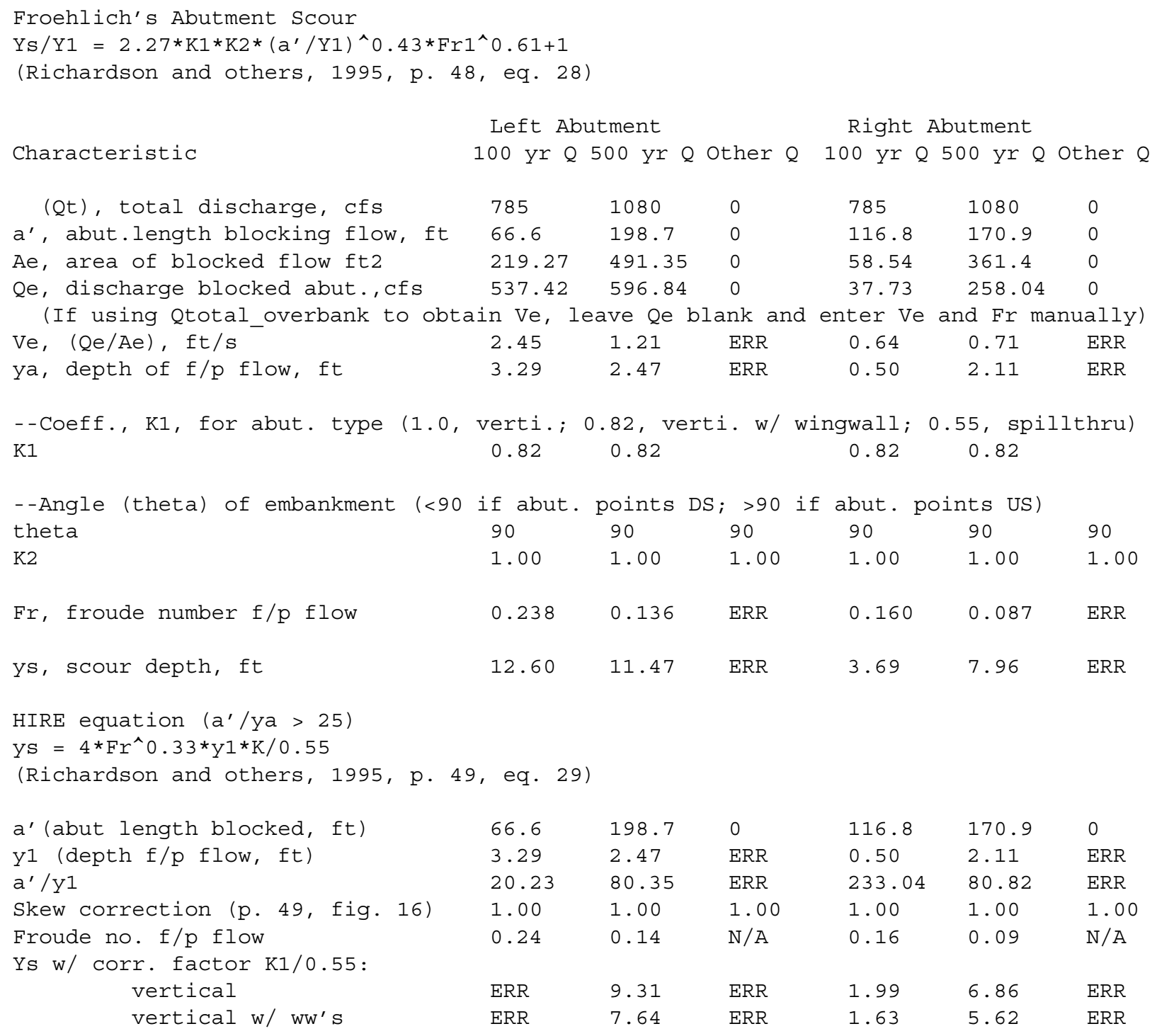




\begin{tabular}{|c|c|c|c|c|c|c|}
\hline spill-through & ERR & 5.12 & ERR & 1.10 & 3.77 & $\mathrm{ERR}$ \\
\hline \multicolumn{7}{|l|}{ Abutment riprap Sizing } \\
\hline \multicolumn{7}{|c|}{$\begin{array}{l}\text { Isbash Relationship } \\
\mathrm{D} 50=\mathrm{Y}^{*} \mathrm{~K} * \mathrm{Fr} r^{\wedge} 2 /(\mathrm{Ss}-1) \text { and } \mathrm{D} 50=\mathrm{Y} * \mathrm{~K} *\left(\mathrm{Fr} r^{\wedge} 2\right)^{\wedge} 0.14 /(\mathrm{Ss}-1) \\
\text { (Richardson and others, 1995, p112, eq. 81,82) }\end{array}$} \\
\hline Characteristic & Q100 & Q500 & Qothe & & & \\
\hline $\begin{array}{l}\text { Fr, Froude Number } \\
\text { (Fr from the characteristic } V \text { and }\end{array}$ & $\begin{array}{l}1 \\
y\end{array}$ in & $\begin{array}{l}0.56 \\
\text { tracte }\end{array}$ & $\begin{array}{l}0 \\
\text { ectior }\end{array}$ & i br & $\begin{array}{l}0.56 \\
\text { sect }\end{array}$ & 0 \\
\hline$y$, depth of flow in bridge, ft & 3.55 & 6.26 & 0.00 & 3.55 & 6.26 & 0.00 \\
\hline \multicolumn{4}{|c|}{ Median stone Diameter for riprap at: left abutment } & \multicolumn{3}{|c|}{ right abutment, ft } \\
\hline Fr<=0.8 (vertical abut.) & $\mathrm{ERR}$ & 1.21 & 0.00 & $\mathrm{ERR}$ & 1.21 & 0.00 \\
\hline Fr>0.8 (vertical abut.) & 1.48 & ERR & $\mathrm{ERR}$ & 1.48 & $\mathrm{ERR}$ & ERR \\
\hline Fr $<=0.8 \quad$ (spillthrough abut.) & ERR & 1.06 & 0.00 & ERR & 1.06 & 0.00 \\
\hline Fr>0.8 (spillthrough abut.) & 1.31 & ERR & ERR & 1.31 & ERR & ERR \\
\hline
\end{tabular}

